\title{
Transhümanizm: “Allah'ın Yarattığını Değiştirme” veya İnsana Karşı Şeytan 2.0
}

\section{Transhumanism: "Changing God's Created" or Devil Against Human 2.0}

\section{İshak Doğan}

Dr., MEB, Mahmut Sami Ramazanoğlu Anadolu Imam Hatip Lisesi

PhD., MEB, Mahmut Sami Ramazanoğlu Anatolian Imam Hatip High School

Konya, Turkey

doganishak@hotmail.com | https://orcid.org/0000-0002-5136-554X

\section{Article Type / Makale Tipi}

Research Article / Araştırma Makalesi

DOI: $10.33420 /$ marife 895568
Article Information / Makale Bilgisi

Received / Geliş Tarihi: 12.03.2021

Accepted / Kabul Tarihi: 28.05.2021

Published / Yayın Tarihi: 30.06.2021

Cite as / Atıf: Ay, Doğan İshak. “Transhümanizm: “Allah'ın Yarattığını Değiștirme” veya İnsana Karşı Şeytan 2.0". Marife 21/1 (2021), 11-36. https://doi.org/10.33420/marife.895568

Plagiarism / Intihal: This article has been reviewed by at least two referees and scanned via a plagiarism software. / Bu makale, en az iki hakem tarafından incelendi ve intihal içermediği teyit edildi.

\section{(c) $(1) \$$}

Copyright / Telif Hakkl: "This article is an open access article distributed under the terms and conditions of the Creative Commons Attribution-NonCommercial-NoDerivatives 4.0 (CC BY-NC-ND 4.0) International License." / "Bu makale Creative Commons Alıntı-GayriTicari-Türetilemez 4.0 (CC BY-NCND 4.0) Uluslar arası Lisansı altında lisanslanmıștır."

e-ISSN: $2630-5550$

www.marife.org 


\section{Transhümanizm: “Allah'ın Yarattığını Değiștirme” veya İnsana Karşı Şeytan 2.0}

\section{Özet}

Transhümanizm, nanoteknoloji, sibernetik, farmakolojik ve gen terapileri dâhil ancak bunlarla sinırlı olmamak üzere biyoteknolojik müdahaleler yoluyla insan yaşamının kalitesini ve uzunluğunu iyileştirme sürecini ifade eder. Batı'da Aydınlanma döneminin ardından teknolojik ve bilimsel gelişmelerle bütün insanlığın mutluluğunun ve huzurunun gerçekleștirilebileceğine inanan modern insan, elde ettiği bașarılarla kâinata hâkim olup onu boyunduruk altına alabileceği, ihtiyaçları ve arzularına göre onu șekillendirebileceğine inanmıștır. Batı'nın vahiy ve dinî otoritenin yerine bilim ve aklı ön plana koymasl, rönesans, reform ve pozitivizmle yoluna devam etmesine ve bu gelişmeler de bir ideoloji ve hareket olarak birbiri ardından hümanizm, modernizm ve şimdilerde transhümanizme geçiş yapmasına neden olmuştur.

Transhümanizm, bilimsel ve teknolojik gelişmelerle sürekli güncellenen ve yeryüzünde yaşanan hayattan daha idealini insanlara vaat eden, her bașarıda geleneği ve dinlerin bir aldatmaca olduğunu ortaya koymaya çalışan bir hareket ya da dindir. Transhümanizm, aşkın ilahi bir varlıktan ziyade insan çabaları ile elde edilen baştan çıkarıcı ölümsüzlük veya radikal yaşam uzatma vaadi ile modern bilim ve teknolojinin gücünü ve potansiyelini özetlemektedir. Oysa insanın kendisini aşabileceğine olan inanç, teknolojinin insanı dönüştürme ve iradesini ele geçirmesine, mekanik ve ruhsuz bir insan ve teknik bir evrenin ortaya çıkmasına neden olmaktadır. Böylece bilimi kullanarak dünyayı daha da yaşanabilir bir hâle getirme hedefi, insanın bilimin kölesi olmasına yol açmaktadır.

Transhümanizmin son yıllarda tüm dünyayı etkilemesi, özellikle Batı'da yayınlanan kimi araştırmalarda İslam ile transhümanizm arasında bir yakınlık kurulabileceği düşüncesine neden olmuştur. Oysa dikkatli bir şekilde incelendiğinde, transhümanizmin hedeflerinin Allah'ın rahmeti ve cennetten kovulan İblis'in insanoğluyla sürdürdüğü mücadelede kullandığı argümanların dışında yer almadığı görülür. Bu açıdan transhümanizm köken itibariyle yeni olmayıp sadece bu șeytanî mücadelenin güncellenmiş şeklini taşımaktadır. Diğer yandan insanı kusurlu olup tamamlanması gereken bir varlık olarak gören transhümanistlerin, aynı nakıs varlıktan mükemmel bir oluşum beklemeleri de kendi içinde bir paradoks taşımaktadır.

İslam'a göre insan ve kâinat mükemmel şekilde yaratılmıştır, yaratma vasfi da Allah'a aittir. Insanı ve dünyayı dönüștürüp fıtratı bozma eğiliminde olan transhümanizm ise, insanı kusurlu bir varlı olarak gördüğünden, mevcut ve gelișen teknolojileri kullanarak inanları post-insana dönüștürmek, insan yaşamını uzatmak ve ölümsüzlüğü keșfetmenin peşindedir. Bu düşüncenin temelini ise, ölümsüzlük, öjeni ve beden üzerinde sınırsız tasarruf hakkını gündeme getirerek, tıbbî ve bilimsel gelişmeler ışığında bunun gerçekleşebileceği oluşturmaktadır. Henüz İslam dünyasında yeterince gündem bulmayan transhümanizm konusu, özellikle Allah'ın kadir-i mutlak ve yaratıcı olması ile kader inancına karşı muhtemel tehlikeler içermektedir.

Bu araștırmada transhümanizmin kısa bir tarihçesi, vaatleri ve hedeflerinin ardından ortaya koyduğu ölümsüzlük, öjeni ve Allah'ın yarattığını değiştirme olarak kabul ettiğimiz beden üzerindeki kalıcı modifikasyonlara Kur'an ve sünnette yer alan ilkelerle cevap verilmiştir. İslam'da ölümsüzlük düşüncesi olmadığı gibi bu düşünce, âhiret inancıyla da çelişir. Diğer yandan müslümanın dünyada uzun yaşamak gibi bir hedefi değil ömrünü salih amellerle bereketli șekilde tamamlamak gibi bir hedefi olabilir. İnsan neslinin ıslahına (öjeni) gelince, İslam'da hayırlı neslin varlığı genlere ya da DNA'lara müdahale ile gerçekleştirilmez. Hayırlı neslin varlığı, dindar eşlerin seçimi ve eşlerin ilişki sırasında bile şeytandan Allah'a sığınmaları ile gerçekleşir. Transhümanizm ise, genler ve insan bedeni üstündeki modifikasyonlarla daha zeki, daha üstün ve biyolojik açıdan daha güçlü bir bedeni kurgulayabilmenin peşindedir. Araştırmada, bu hedeflerin yeni olmayıp Nisa sûresinin 119. âyetinde, şeytanın insanoğluna yönelik mücadelesini açıkladığı, "Onları mutlaka saptıracağım, mutlaka onları kuruntulara sokacağım. Ve onlara emredeceğim de (putlara adak için) hayvanların kulaklarını yaracaklar. Yine onlara emredeceğim de Allah'ın yarattığını değiștirecekler" âyetinde yer aldığı gösterilmiştir. Özellikle insan bedeni üzerinde yapılan kalıcı değişiklikler, müfessirlerin görüşleri ile açıklanmıştır. Disiplinler arası bir özellik taşıyan bu konu, Kur'an, hadis ve tefsir bağlamında değerlendirilmeye çalışılmıştır.

Anahtar Kelimeler: Tefsir, Transhümanizm, Öjeni, Ölümsüzlük, Şeytan. 


\section{Transhumanism: “Changing God's Created” or Devil Against Human 2.0}

\section{Summary}

Transhumanism refers to the process of improving the quality and length of human life through biotechnological interventions, including but not limited to nanotechnology, cybernetics, pharmacological and gene therapies. Believing that after the Enlightenment period in the West, the happiness and peace of all humanity can be achieved with technological and scientific developments, the modern man assumed that he could dominate the universe with his achievements, subjugate it, and shape it according to his needs and desires. The predominance of science and reason instead of revelation and religious authority by the West has caused it to continue its way with renaissance, reform, and positivism, and these developments have led to humanism, modernism, and now transhumanism as an ideology and movement.

Transhumanism is a movement or religion that is constantly updated with scientific and technological developments and it promises people something more ideal than life on earth and tries to reveal that tradition and religions are a deception in every chance it gets. Transhumanism summarizes the power and potential of modern science and technology with the seductive promise of immortality or radical life extension achieved by human efforts rather than a transcendent divine being. However, the belief that human beings can transcend themselves causes technology to transform human beings and seize their will, and the emergence of a mechanical and soulless human and a technical universe. Thus, the goal of making the world more livable by using science causes humans to become slaves of science. According to Islam, man and the universe have been created perfectly, and the quality of creation belongs to Allah. Transhumanism, which tends to transform the human and the world and distort nature, seeks to transform believers into post-human beings by using existing and developing technologies, to prolong human life and to discover immortality because it sees humans as flawed beings. The subject of transhumanism, which has not yet been on the agenda in the Islamic world, poses great dangers to belief in destiny, especially to the fact that Allah is omnipotent and creative.

In this study, a brief history of transhumanism is given. The questions of its promises and goals, immortality, eugenics, and permanent modifications on the body, which we consider as to change what is created by God, are answered with the principles of the Qur'an and sunnah. Just as there is no thought of immortality in Islam, the mere idea of it also conflicts with belief in the hereafter. As for the improvement (eugenics) of the human generation, the existence of the good generation in Islam is not achieved by interfering with genes or DNA. The good generation is expected to be realized by the selection of religious spouses and taking refuge in Allah from Satan in every aspect of their lives. Transhumanism, on the other hand, seeks to construct a more intelligent, superior, and biologically stronger body with modifications on the human. In the research, it's been showed that these goals are not new and that in the 119th verse of the chapter of Nisa, Allah explains the struggle of the devil against man, "I will mislead them, and I will create in them false desires; I will order them to slit the ears of cattle, and to deface the (fair) nature created by Allah." Especially the permanent changes made on the human body were explained by the opinions of the tafsir scholars. This issue, which has an interdisciplinary feature, has been tried to be evaluated in the context of the Quran, hadith, and interpretation.

Keywords: Tafsir, Transhumanism, Eugenics, Immortality, Satan.

\section{Giriş}

Teknolojinin hızlı bir şekilde insan yaşamını dönüştürmesi, nanoteknoloji, biyoteknoloji, robotik bilgi ve iletişim teknolojisi ile uygulamalı bilişsel bilimin yakınsaması, insanın bir tasarım projesi haline geldiği yeni bir durumu ortaya çıarmıştır. İnsanlık artık, yeni teknolojiler, yapay zekâyı ara yüz teknolojisi, moleküler biyoloji ve nanoteknoloji ile birleștiren yeni tür bilişsel araçlarla zihinsel ve fiziksel kapasitelerinin genetik olarak güçlendirilmesi, hastalıklarla mücadele etmek ve yaşlanma sürecini yavaşlatmak, arzular, ruh halleri ve zihinsel durumlar üzerinde kontrolü sağlamak gibi bilim ve teknolojinin eşliğinde gündeme gelen yeni gelişmeler ve problemlerle karşı karşıya kalmıştır. Genetik mühendisliği nedeniyle, insanlar artık yalnızca kendilerini yeniden tasarlayıp muhtemelen çeşitli sınırlama- 
lardan kurtulmakla kalmamakta, aynı zamanda gelecek nesilleri yeniden tasarlamaya kalkışmakta ve böylece insanın dönüșüm sürecinin kendisini etkilemektedir. Sonuç olarak insanların daha uzun yaşayacağı, yeni fiziksel ve bilişsel yeteneklere sahip olacağı, yaşlanmaya ve hastalıklara bağlı olarak acı ve acıdan kurtulacağı yeni bir post-insan aşaması için çaba gösterilmektedir. ${ }^{1}$

Felsefi açıdan kökleri aydınlanma dönemine ulaşan transhümanizm², nanoteknoloji, sibernetik, farmakolojik ve gen terapileri dâhil ancak bunlarla sınırlı olmamak üzere biyoteknolojik müdahaleler yoluyla insan yaşamının kalitesini ve uzunluğunu iyileştirme sürecini ifade eder. Aydınlanma dönemiyle birlikte akıl ve bilimin Batı'da kazandığı başarılar, kendisine ayrılmış alanın daha da genişlemesine sebep olmuş ve dinî dogmatizmin yerine bilimin insan hayatını daha mükemmel hâle getirebileceğine dair inancı arttırmıştır. Hatta o dönemde Marquis de Condorcet (ö. 1795), Benjamin Franklin (ö. 1790) ve William Godwin (ö. 1836), insanların sadece zulüm ve eşitsizliği değil, aynı zamanda ölüm ve hastalı̆̆ı da yenebileceğini, Denis Diderot (ö. 1784) ise insanlığın çok çeşitli post-insan türlerine dönüşebileceğini öne sürmüştür. ${ }^{3}$

Transhümanizm kelimesini ilk olarak 1927 yılında Aldoux Huxley'in evrimsel biyolog ve öjenikçi (insan neslinin ıslahını savunan) kardeşi Julian Huxley (1887-1975), Religion Without Revelation adlı makalesinde "bilim ve teknolojiyi kullanarak insan ırkının evrimini mevcut sınırların ötesine taşımayı amaçlayan bir hareket" olarak kullanmıştır. ${ }^{4}$

İsveçli filozof Nick Bostrom (doğ. 1973), transhümanist ilk çabanın Sümerlerin Gılgamış destanında geçen Kral Uruk'un ölümsüzlük arayışında ve Zeus'tan ateşi çalan Prometheus'ta görüldügünü söyler. ${ }^{5}$ Transhümanizmin hastalıkların ve acıların ortadan kaldırılması, insanın entelektüel, fiziksel ve duygusal yeteneklerinin arttırılmasının yanı sıra, ekonomik, sosyal ve kurumsal tasarımlar, kültürel gelişim ve psikolojik beceri kazandırmanın da hedefleri arasında yer aldığını ifade eden Bostrom, transhümanistlerin, insan doğasına arzu edilen biçimde yeniden şekillendirilebilecek yarı pişmiş bir başlangıç olarak baktıklarını, teknoloji ve bilimsel çalışmalar sonunda günümüz insanlarının sahip olduğundan daha büyük kapasitelere sahip post-insanlar olmayı başaracağını iddia eder. Genel hatlarıyla bu çalışmaların, çok daha uzun ve daha sağlıklı yaşamlar, hafızamızı ve entelektüel yeteneklerimizi geliştirme, refah duygumuzu arttırma, kısacası eksik olduğu iddia edilen dünya yaşamının tamamlanmasını sağlayacağını belirtir. Bu aşamada anlamlı insan ilişkileri ve ekolojik problemlerin yașanabileceğini ancak tüm bunların

1 Hava Tirosh-Samuelson, Kenneth L. Lossman, Building Better Humans: Refocusing the Debate on Transhumanism (Frankfurt: Peter Lang, 2011), 29.

2 Andrew Edgar, "The Hermeneutic Challenge Of Genetic Engineering: Habermas And The Transhumanists". Medical Health Care Philosophy 12(2) (June 2009), 157-67.

3 James J. Hughes, J., "The Politics of Transhumanism and the Techno-Millenial Imagination 1626-2030", Zygon 47/4 (December 2012), 760.

4 Peter Harrison-Joseph Wolyniak, "The History of Transhumanism”, Notes and Queries 62/3 (September 2015), 465-467.

${ }^{5}$ Nick Bostrom, "A History of Transhumanist Thought", Journal of Evolution and Technology 14/1 (April 2005), 1. 
insanın ulaşabildiği düşünceler, duygular, deneyimler ve faaliyetler karşısında küçük bir bölüm oluşturduğunu ve transhümanizmin teknolojik iyimserlik gerektirmediğini itiraf eder. ${ }^{6}$

Akla inanç, bireycilik, bilim, ilerleme ve kendi kendini mükemmelleștirme gibi seküler ve aydınlanmanın etkisindeki hümanist düşüncenin merkezi yönlerini kucaklayan transhümanizm ${ }^{7}$, insanın biyolojik kapasitelerinin ve sosyal koşullarının teknoloji aracılığıyla radikal dönüșümünü doğrulayan bir duruș olarak da tanımlanabilir. Transhümanizmin temel amacı, insanları post-insana dönüştürmek, insan yaşamını uzatmak, ölümü geciktirmek ve ölümsüzlüğü keşfetmektir. ${ }^{8} \mathrm{Bu}$ amaçları gerçekleştirmek için, transhümanistlerin bilimsel ilerlemeye kesin bir güvenleri vardır. Dolayısıyla transhümanizm, belirli teknolojilerle sınırlı değildir, vizyonlarını gerçekleștirmek için her türlü aracı kucaklar. ${ }^{9}$ Ancak temelde üç teknolojik ilerlemeye bağlıdır: Dünya üzerinde tam kontrol sağlamaya neden olacak nanoteknoloji, yaşlanmayı ve ölümü ortadan kaldıracak olan gelişmeler ve son olarak bilgisayar alanındaki gelişmelerle yapay zekânın üst seviyeye çıkarılması. ${ }^{10}$

Transhümanizmin değerleri de şu şekilde sıralanır: Daha iyi bir yaşam için doğaya müdahale, geliştirme teknolojilerinin kullanımında bireysel seçim; barıș, uluslararası işbirliği, kitle imha silahlarının yayılmasının önlenmesi; anlayışı ve eleştirel düşünmeyi geliştirmek; bireysel ve toplumsal anlamda daha üstün zekâya sahip olmak ve makinelerin zekâsını geliștirmek; felsefi yanılabilirlik; pragmatizm; ırklar, dini inançlar, cinsel yönelimler ve yaşam tarzlarında çeşitlilik; tüm insanların iyiliğini önemsemek; hayat kurtarmak (ömrü uzatma, yaşlanmayı geciktirme vs.). ${ }^{11}$ Değerlerini bu denli frapan ifadelerle açıklasa da gelișimi ve geleceği itibariyle bir belirsizlik taşımasından dolayı transhümanizm, birçok bilim adamı tarafından şüpheyle karşılanmaktadır.

Teknoloji ve bilimdeki ilerlemeler, insanlığın zaaf noktası olan acıların ve hastalıkların son bulma ihtimali, bütün dinlerin âhiret için vaat ettiği ölümsüzlük, mutluluk ve cennet hayatının mükemmelliği gibi argümanları transhümanizmin de dünya için kullanıyor oluşu, onun dinler karşısında bir tehdit unsuru olmasına neden olmaktadır. Dinlerin insanlara vaat ettiği ruhsal tatmin ve daha huzurlu bir yaşam hedefi, transhümanizmde biyolojik ve zihinsel sınırların sona ereceğinden dolayı mutluluk ve daha üstün bir yaşam tarzına dönüşmüştür. $\mathrm{Bu}$ yönüyle transhümanizm bir hareketten ziyade bir din olarak tanımlanabilir. Huxley'in Religion without Revelation (Vahiysiz Din) adlı eseri de, isminden anlaşlacağı üzere transhümanizmin kendisini din olarak benimsetme eğilimi taşıdığını göstermekte-

6 Nick Bostrom, "Transhumanist Values, Ethical Issues for the Twenty-First Century", Review of Contemporary Philosophy 4 (May 2005), 3-4.

7 Robert Ranisch-Stefan Lorenz Sorgner, "Intoducing Post-and Transhumanism", Post-and Transhumanism (Frankfurt: Peter Lang, 2014), 7-8.

${ }^{8}$ Hans-Jörg Kreowski, "Transhumanism and Nanotechnology-Will Old Myths Come True?", Proceedings 1 (June 2017), 1.

${ }^{9}$ Robert Ranisch-Stefan Lorenz Sorgner, "Intoducing Post-and Transhumanism”, 13.

10 Aysel Demir, "Ölümsüzlük ve Yapay Zekâ Bağlamında Transhümanizm”, Online Academic Journal of Information Technology $9 / 30$ (2018), 96

${ }^{11}$ Bostrom, "Transhumanist Values", 13. 
dir. Nitekim insanın nasıl olması gerektiğine dair kurallar ve dinlerdeki gerçekliğin aksine ütopik bir yaşamı barındırdığından dolayı Steven Goldberg (ö. 2010), transhümanizmi bir din olarak kabul etmiştir. ${ }^{12}$ Üstelik bu din, Huxley'in iddia ettiği gibi vahiysiz değildir; bu yeni dinin vahyini, öğretilerini ve değerlerini artık Batılı düşünür ya da filozoflar değil, önü alınamayan bilimsel ve teknolojik gelişmeler belirlemektedir. Bir anlamda Aydınlanma sonrası pozitivizmle bilimi ön plana çıkaran ve ona hâkim olmaya çalışan Batı, artık önünü alamadığı teknolojik gelişmelerin hâkimiyeti altına girmiştir. Bununla birlikte, transhumanizmin mükemmellik arayışı, insanın iyileştirilmesine odaklanma; endişe, yoksulluk, hastalık ve acı gibi sosyal hastalıkları ortadan kaldırarak toplumun iyileşmesi için çaba gösterme gibi geleneksel dinlerle birçok unsur paylaştığını da not etmek gerekir. ${ }^{13}$

Bu teknolojik gelişmelerle birlikte transhümanizm, insan ve kâinat üzerinde bir dönüşüm sağlayabileceğine dair üç hususu öne çıkarmıştır ki bunlar da ölümsüzlük ve yaşlanmayı geciktirme, öjeni ve insan bedeni üzerindeki modifikasyonlarla onu kusursuz bir hâle getirme çabalarıdır.

\section{1. Ölümsüzlük}

İnsanlığın, son yüzyılda dünyada kıtlık, salgın ve savaşlara son verme gücünü eline aldığından bahseden transhümanistlerin en büyük iddiası, insanın ölümsüz olabileceği fikridir. ${ }^{14}$ Bilim ve teknoloji sayesinde kimi hastalıkları, acıları ve biyolojik kusurları ortadan kaldırmada bir başarı sağlayan insanoğlu, zafer sarhoşluğu içinde ölümsüzlüğe ulaşabileceği hayaline de kapılmıştır. Bu hayalini aşkın bir varlıktan daha çok bilimsel gelişmelere bağlayan transhümanizm, dinden rol çalmakla kalmayıp kendisini Tanrı yerine koymaya çalışmış, dünya sahnesinde felsefesinin itibar görmesi için en büyük iddiası da zorunlu olarak ölümsüzlük olmuştur. ${ }^{15}$ Aslında insanı kusurlu bir varlık olarak görüp mükemmelleștirmeye kalkışan bu hareketin, hayata hâkim olan ilahî kanunları da eksik görmesinden daha normal bir şey yoktur. Genetik mühendislik, klonlama, biyonikler ve nanoteknoloji gibi alanlarda yaşanan gelişmeler doğal olarak ölümsüzlük ihtimalini zihinlere düşürmüştür. Bu plana göre gelişim teknolojileri yoluyla insanlar post-humana dönüşecek ve böylece kendisini programlayan ölümsüz bireyler hâlini alacaktır. ${ }^{16}$

Transhümanizmin en büyük savunucularından Yuval Harari (doğ. 1976), ölümün üstesinden gelebileceklerini söyleyerek insanlık için yeni hedefin tanrılık mertebesine çıkmak olduğunu söyler. ${ }^{17}$ Ona göre birçok kimse artık ölümsüzlüğün mümkün olduğuna inanmakta, hatta genetik mühendisliği ve nanoteknoloji gibi

${ }^{12}$ Steven Goldberg, "Does The Wall Still Stand? The Implications Of Transhumanism For The Separation Of Church And State”, Georgetown Public Law Research Paper 09-10 (May 2009), 1-7.

13 Hava Tirosh-Samuelson, "Religion", Post-and Transhumanism, ed. Robert Ranisch-Stefan Lorenz Sorgner (Frankfurt: Peter Lang, 2014), 60.

${ }^{14}$ Hughes, "The Politics of Transhumanism”, 760-768.

15 Ahmet Dağ, “Hümanizmin Radikalleşmesi Olarak Transhümanizm”, Felsefí Düşün 9 (Ekim 2017), 5256.

16 Dağ, "Hümanizmin Radikalleşmesi", 59-64.

17 Yuval Noah Harari, Homo Deus: Yarının Kısa Bir Tarihi (İstanbul: Kolektif Kitap, 2016), 32. 
alanlardaki gelişmelere bakan kimi uzmanlar, 2100 ya da 2200 yılında ölümü yeneceklerini iddia etmektedirler. ${ }^{18}$ "Ölümsüzlük çanları çalan bilim insanları, kurt var diye bağıran yalancı çoban gibi görünseler de kurt er ya da geç gelecektir"19 diyen Harari, insanlığın yeni hedefinin ölümsüzlük, mutluluk ve tanrısallık olduğunu söyler. ${ }^{20}$ Ray Kurzweil de (doğ. 1948), geçmişin aksine günümüzde teknolojiden faydalananların biyolojik insandan ayrlarak 'İnsan 2.0' sürümüne geçtiğini ve yakın bir gelecekte de bedenleri değiștirebilme gücüne sahip olup 3.0 sürümüne geçeceklerini iddia eder. ${ }^{21}$

Dijital teknoloji, transhümanistleri ölümsüzlük ve yaşamı kontrol edebilme hayallerine teşvik etmiştir. ${ }^{22} \mathrm{Bu}$ nedenle biyolojide ölümün kaçınılmaz değil, sadece biyologların ölüme neden olan șeyi keşfetmelerinin geciktiğine inanmaktadırlar. ${ }^{23}$ Umutlarını kaybetmeyip ölümsüzlüğün gerçekleşebileceğine inananlar, ya makinelere nöronları ve hücreleri kopyalayarak zihni aktarma yoluyla gerçekleștirilen Konektom Projesi veya zihnin henüz bilinçli iken ölümsüz bir robota aktarılması ya da nanobotlar yoluyla bunun gerçekleşeceğine inanmaktadır. ${ }^{24}$

Diğer yandan ölümü, hayatın bir parçası olarak görmekle Hristiyanlık, İslamiyet ve Hinduizmin yanlıșa düștügünü savunan transhümanistler, ölümsüzlüğün elde edilmesiyle dinlerin yok olup bilimin hâkim olacağını savunurlar. ${ }^{25} \mathrm{Bu}$ anlamda transhümanizm, aşkın bir inanç taşıyan tüm dinlerin karşısında ve pozitivizmin zirvesinde yer alır.

Esasen transhümanizmin bu iddiası; Hz. Peygamber'in çağlar ötesinden haber verdiği bir gelişmedir: "Âdemoğlu ihtiyarlar, fakat şu iki şey onunla beraber genç kalır; dünya hırsı ve uzun yaşama duygusu." 26 Bireysel anlamda insan için geçerli olan bu bilgiden hareketle insanlığ bir yaşam çizgisinde ele aldığımızda, kıyamete yaklaştıkça ihtiyarlayan insanlığın iki konudaki hırsının devam ettiğini de söyleyebiliriz.

Kimi transhümanistler, ölümsüzlük düşüncesinin kökenini Hz. Âdem'e dayandırsa da aslında tarihsel olarak transhümanizmin ilk izlerini Âdem'i, Rabbine karşı itaatsizliğe sürüklemeye çalıșan şeytanda buluruz. Belki de bu düşüncenin şeytandan kaynaklandığının bilinmesi, semavî dinlere inanan kesimlerin transhümanizme ön yargıyla yaklaşmasına neden olacağından dolayı bu düşüncenin ilk olarak, ilk insanda ortaya çıktığı iddia edilmiştir. Oysa Allah'ın, Âdem'e secde etmesi emrine karşı çıkan şeytan, bu itaatsizliğinden dolayı Allah'ın huzurundan kovulunca haklılığını ispatlama amacıyla diriliş gününe kadar kendisine dünyevî ölümsüzlük ya da süre tanınmasını istemiș, Allah da onun bu isteğine: "Haydi, sen

\footnotetext{
${ }^{18}$ Harari, Homo Deus, 36; Michio Kaku, Geleceğin Fiziği (Ankara: ODTÜ Yayıncılık, 2016), 150.

${ }^{19}$ Harari, Homo Deus, 40.

${ }^{20}$ Harari, Homo Deus, 32.

${ }^{21}$ Ray Kurzweil, İnsanlık 2.0, çev. Mine Şengel (İstanbul: Alfa Yayınları, 2016), 464.

22 Rosi Braidotti, Insan Sonrası (İstanbul: Kolektif Kitap, 2013), 127.

${ }^{23}$ Kaku, Geleceğin Fiziği, 213.

${ }^{24}$ Michio Kaku, Zihnin Geleceği (Ankara: ODTÜ Yayıncılık, 2014), 323-330.

${ }^{25}$ Harari, Homo Deus, 33.

${ }^{26}$ Müslim b. Haccac el-Kușeyrî, Sahih-i Müslim, thk. Muhammed Fuad Abdulbâkî (Beyrut: Dâru İhyâi'tTurâsi'l-Arabî, trs.), "Zekât” 1046.
} 
mühlet verilenlerdensin"27 cevabıyla karşllık vermiştir.

İnsanların tekrar diriltilecekleri güne kadar süre isteyen şeytanın bu sözleri, kıyamet günü her canlının öleceğine dair kesin inancını gösterir. Aslında yeryüzünde halife olmak üzere yaratılmış insan karşısında aldığı bu ağır yenilgi, onu Âdem ile Havva'yı da aynı âkıbete sürüklemeye sevk etmiş, dönüşü olmayan bir günah ile Allah'ın rahmetinden kovulan şeytan, onları da bir günah ile Allah'ın rahmetinden uzaklaştırmak istemiştir.

Allah'ın, "Ey Âdem! Sen ve eşin cennete yerleşin. Orada dilediğiniz gibi bol bol yiyin, ama şu ağaca yaklaşmayın, yoksa zalimlerden olursunuz" ${ }^{28}$ uyarısı karşısında, insandaki 'melekleşme' ya da 'cennette ebedî kalma' arzusunu fark eden ve o ana kadar mücadelesini dışarıda sürdüren şeytan, Âdem ile Havva'ya yasaklanan ağacın 'ebedîlik ağacı' olduğunu fisıldayarak içlerine girmiş ve: "Ey Âdem! Sana ebedîlik ağacını ve yok olmayan bir saltanatı göstereyim mi?" 29 ve "Rabbiniz size bu ağacı ancak, melek olmayasınız, ya da (cennette) ebedî kalacaklardan olmayasınız diye yasakladı"30 sözleriyle onları kandırmaya kalkışmıştır. Aslında şeytan, Âdem ve Havva'ya Allah'a itaatsizlik etmelerini söylememiş, onlara fisıldayıp kalplerine birtakım arzular düşürmüștür. İnsanlığın atasını aldatmış olmasının verdiği bu başarı, o andan itibaren şeytanın bu çağrısını Âdemoğullarının kulaklarına da sürekli fisıldamasına neden olmuştur.

Ölümsüzlük hayali, insanî bir eğilimdir. Ancak İslam'da ölümsüzlük, cennet ve cehennem hayatı için geçerli iken, transhümanizm ile bu düşünce dünyevî bir boyuta taşınmış, cennetten çıkmak istemeyen insanoğlu bu kez de dünyadan ayrılmama umuduyla karşı karşıya kalmıştır. İslam inancında imanın şartlarından olan âhiret gününün varlığına iman, ölümün de mutlak olarak gerçekleșeceğine imanı ifade eder. Öleceğine kesinlikle iman eden müslümanın dünyada ölümsüz olmak gibi bir problemi yoktur ve böyle bir şeye de ihtimal vermez. Çünkü müslüman inanır ki; "Allah, eceli geldiğinde hiçbir kimseyi asla ertelemez"31, "Her nefis ölümü tadacaktır"32 ve "Her ümmet için belirlenmiş bir ecel vardır."33 $\mathrm{Ne}$ yaparsa yapsın onun için ölümden kurtuluş yoktur. ${ }^{34}$ Nitekim Hz. Peygamber, "Allah, indirdiği her hastalık için mutlaka bir şifa da indirmiştir; ancak ölüm ve ihtiyarlık hariç" buyurmuștur.

Onu endișelendiren tek șey, ebedî hayatını cennette mi yoksa cehennemde mi geçireceği, hayatını hüsn-ü hatime ile tamamlayıp tamamlayamayacă̆ıdır. 0 , ölümsüzlük değil, amel defterini kapatmayacak sadaka-i cariyeler bırakmak için

\footnotetext{
${ }^{27}$ Kur'an-ı Kerim Meâli, çev. Hayrettin Karaman-Mustafa Çağrıcı vd. (Ankara: Diyanet İşleri Başkanlığı Yayınları, 2017) el-A'râf 7/15; el-Hicr 15/37.

28 el-Bakara 2/35; el-A'râf 7/19.

29 Taha 20/120.

30 el-A'râf 7/20.

31 el-Münafikûn 63/11.

32 Âl-i İmran 3/185.

33 el-A'râf 7/34.

34 en-Nisa 4/78.

${ }^{35}$ Ebu Abdillah Ahmed b. Muhammed b. Hanbel, el-Müsned, thk. Şuayb el-Arnaûd (Müessesetu'r-Risale, 2001), 30/394.
} 
uğraşır. Allah katında dünyanın bir sivrisinek kanadı kadar değeri olmadığını ${ }^{36}$, dünya hayatının gelip geçici bir oyun ve oyalanmadan ibaret olduğunu ve gerçek hayatı ancak âhirette yaşayacağını ${ }^{37}$ bilir. Ömrü uzatma ya da yaşlılığı geciktirmeye gelince, bu konuda her șeyin Allah'ın elinde olduğuna ve tüm bunların yaratılmadan önce takdir edildiğine inanır. "Herhangi bir kimseye uzun ömür verilmez yahut ömrü kısaltılmaz ki bu bir kitapta (Levh-i Mahfuz'da yazılı) olmasın."38 "Aranızda ölümü takdir eden biziz. Ve biz, önüne geçilebileceklerden değiliz."39 Allah'ın takdiri olmaksızın hayatı uzatmak mümkün olmadığı gibi O'nun takdiri olmaksızın ölüm de mümkün değildir: "Hiçbir kimse Allah'ın izni olmadan ölmez. Ölüm belirli bir süreye göre yazılmiştır." 40

Bununla birlikte, Kur'an'da iman ve birtakım hayırlı amellerin ölümü geciktireceğine dair ifadeler vardır. Örneğin Nuh (as) kavmine şöyle der: "Allah'a ibadet edin. O'na karşı gelmekten sakının ve bana itaat edin ki, sizin günahlarınızı bağışlasin ve sizi belli bir vakte kadar ertelesin. Şüphesiz, Allah'ın belirlediği vakit gelince ertelenmez." 41 Kimi müfessirler, iman etmeleri durumunda Nuh kavminin ömrünün 1000 yıl, küfürde kalmaları halinde ise 900 yıl olarak takdir edildiğini, süre tamamlandığında da ölümlerinin geldiğini belirtmişlerdir. ${ }^{42}$

Bunun yanı sıra Hz. Peygamber dua, sıla-i rahim, anne-babaya iyilik gibi fiillerin ömrü arttırıp eceli geciktireceğini belirtmiştir. "Kaderi ancak dua reddeder, ömrü de ancak iyilik arttırır." 43 "Ömrünün uzun, rızkının bol ve kötü ölümden uzak olmayı isteyen kişi, Allah'tan korksun ve akrabalık bağlarını gözetsin" 44 şeklindeki hadisler, kimi ibadetlerin ömrü uzatacağına işaret etse de, Ehl-i Sünnet'e göre bununla kastedilen şey tedbirleri alıp sağlık kurallarına uyarak uzun süre yaşayanların da, hastalanarak ya da tedbirsizlik göstererek kısa süre yaşayanların da ömrünün Allah tarafından bilindiği ve bu bilginin bir kitapta yazılmış olup bununla kastedilenin ömrün bereketli olduğudur. ${ }^{45}$ Konu hakkında kelâmî tartışmalara girmeden söz konusu salih amelleri işleyenlerin mutlak olarak uzun bir hayata sahip olmadıkları gerçeği de Ehl-i Sünnet'in görüşünü daha muteber kılmaktadır. Ömrün artması ya da eksilmesine neden olan bu ameller aslında ömrün bereketli oluşuna işaret etse de, Allah'ın kendi takdir ettiğini silme kudretine sahip olması ile çelişmez: "Her ecelin (vadenin) bir yazısı vardır. Allah, dilediğini siler, dilediğini de sabit

36 Muhammed b. İsa et-Tirmizî, Sünenu't-Tirmizî, thk. Beşşar Avvad (Beyrut: Dâru'l-Ğarbi'l-İslamî, 1998), "Zühd" 13.

37 el-En'am 6/32; el-Ankebut 29/64.

38 el-Fatır 35/11.

${ }^{39}$ el-Vakıa 56/60.

40 Âl-i İmran 3/145.

${ }^{41}$ Nuh 71/3-4.

42 Fahruddin Ebu Abdillah Muhammed b. Ömer er-Râzî, Mefatihu'l-ğayb (Beyrut: Dâru İhyâi't-Turâsi'lArabî, 1420), 30/650; Ebu'l-Fida İmaduddin İbn Kesir, Tefsiru'l-Kur'ani'l-azîm, thk. Muhammed Huseyn Şemsuddin (Beyrut: Dâru'l-Kütübi'l-İlmiyye, 1419) 8/245.

${ }^{43}$ Ahmed b. Hanbel, el-Müsned, 37/95; Tirmizî, "Kader" 6.

${ }^{44}$ Ahmed b. Hanbel, el-Müsned, 2/387, 21/93.

45 Mes'ud b. Ömer b. Sadeddin et-Taftezânî, Şerhu'l-makâsıd, thk. Dr. Abdurrahman Umeyra (Beyrut: Âlemu'l-Kütüb, 1998), 4/314-315. 
kılıp bırakır. Ana kitap (Levh-i Mahfuz) O'nun yanındadır."46 Yani Allah, dilerse yazdığı kaderi bir başka kaderi yazarak iptal eder. ${ }^{47}$ Buna göre Allah, ezelî ilmiyle kulun yapacağı amelleri bildiği için kaderini ona göre şekillendirmektedir.

$\mathrm{Bu}$, ölüm ve ecelin, Allah'ın bu kâinat için yaratmıș olduğu nedensellik yasasına tabi olmadığı anlamına gelmez. Sebebi ve o sebebe bağlı sonucu yaratan yine Allah'tır. ${ }^{48} \mathrm{Bu}$ dünyada takdir edilen her şey gibi, ölüm de Levh-i Mahfuz'da yazılı maddî sebeplere dayanmaktadır. Ölümün, uçurumdan düşme, savașta derin bir yara alma ya da ciddi hastalıklar gibi maddî nedenleri olduğu gibi sağlığı korumak ya da tehlikeli yerlerden uzak durmak gibi onu geciktiren maddî nedenleri de vardır. Allah, kullarının başına gelecek olan musibetleri, mahrumiyetleri, ölümü ve diğer hususları yazmıştır. Eğer kul, Allah'a dua eder veya sıla-i rahim gibi fiilleri ișlemekte O'na itaat ederse, ona bu belâ isabet etmez. Rızkı artar, ömrü uzun ya da bereketli olur. Sonuç olarak her iki durumda da olacak şeyler Levh-i Mahfuz'da yazılmıştır. ${ }^{49}$

Transhümanizm her ne kadar salt uzun bir yaşam veya yaşlanmayı geciktirmeyi hedeflese de müslüman için değerli olan salih amellerle dolu, bereketli bir hayattır. Tıbbî gelişmelerden faydalanarak Allah'ın takdirine karşı koyabilme düşüncesi taşımaz. Bunun yanında İslam'da sağlık söz konusu olduğunda bazı haramların zarureten yasaklama kapsamının dışına alınması, İslam'ın insan bedenine verdiği önemi gösterir. Bedenin, Allah'ın verdiği bir emanet olduğuna inanan müslüman da onu korumak için gereken her şeyi yapar. Nitekim Hz. Peygamber'in özellikle koruyucu hekimlik bağlamında değerlendirilebilecek sağlıklı yașamla ilgili birçok hadisi vardır ki, bu konuda, "Ey Allah'ın kulları, tedavi olun. Allah, verdiği her hastalığın mutlaka şifasını da yaratmıştır" ${ }^{50}$ hadisi konu için yeterlidir.

Modern hayatın şartları, insanların inandıkları gibi yaşamalarına değil yaşadıkları gibi inanmalarına neden olmuştur ki artık şehirlerin dışına taşınan mezarlıklar bunun en açık örneğidir. Her an ölümün gerçekleșebileceği fikri, ölümü hatırlatan her şeyin hayattan uzaklaştırılmasıyla bastırılmaktadır. Oysa yaşadıkları hayattan daha güzeliyle öldükten sonra karşılaşacaklarına inanan müminler için ölüm, bir son veya bir yok oluş değil cennete açılan bir rahmet kapısıdır. Onlar, Allah katında kendilerini bekleyen cennet ve nimetlerin sonsuz olduğuna inanırlar. Allah'a kavuşmak istedikleri için Allah da onlara kavuşmayı diler. ${ }^{51} \mathrm{Bu}$ yüzden hayatın da ölümün de hayırlısını ister, daha değerli olanı geçici olan bir hayatla değişmezler. Ancak şeytanın, ölümsüzlük ya da yaşlanmayı geciktirme düşüncelerini insanların kulaklarına fisıldaması, ikinci bir hayattan ve yok olmaktan korkan transhümanistlerin dünyada kalmak için her yolu denemelerinin önünü açmakta-

${ }^{46}$ er-Ra'd 13/38-39.

47 Ömer en-Nesefî, Metn-i Akâid, çev. H. Tahsin Feyizli (İstanbul: y.y., 1988), 140.

${ }^{48}$ el-En'am 6/17; Yunus 10/107.

49 Ahmed b. Huseyn b. Ali el-Beyhâkî, el-Kadâ ve'l-kader, thk. Muhammed b. Abdillah (Riyad: Mektebetu'l-Ubeykân, 2000), 314.

${ }^{50}$ Muhammed b. İsmail el-Buhârî, Sahihu'l-Buhârî, thk. Muhammed Zuheyr (Dâru Tavki'n-Necât, 1422) "Tıb" 1; Tirmizî, "Tıb" 2.

51 Ebu Davud Süleyman b. Davud et-Tayalisî, el-Müsned, thk. Dr. Muhammed b. Abdilmuhsin (Mısır: Dâru Hecer, 1999), 1/468; Buhârî, "Rikâk" 41; Müslim, "Zikir" 2683-2684. 
dir.

\section{2. Öjeni (İnsan Neslinin Islahı)}

İlk olarak 1883 yılında Darwin'in kuzeni İngiliz bilim adamı Francis Gaton'un (ö. 1911) ortaya attı̆̆ ve kökeni Platon'a kadar uzanan 'öjenik' kelimesi, 'iyi yaratılış' veya 'asil kalıtım' anlamına gelen Yunanca 'eugenics' kelimesinden alınmıştır. Bu akım, kalıtsal özellikleri geliștirme ya da bozuklukları düzeltme amacıyla genetik kompozisyonun özel birtakım yöntemler kullanılarak değiştirilmesini ve insan varlığını iyileştirmeyi savunur. ${ }^{52}$

İlk olarak Platon'un ortaya attığı bu görüșe göre, güçlü devlet ve mükemmel toplumun temelini oluşturacak sağlıklı bir nesil için evrimleşme savunulmalıdır. Ona göre güçlü bir nesil için gen açısından erkek ve kadınlar da seçilmeli, bu iş topluma bırakılmamalıdır. Aksi halde iyi cins kuş ve köpeklerin cinslerinin bozulacağı gibi insan nesli de bozulur. Ancak yararlı olan evliliklerin kutsal sayılabileceğini söyleyen Platon, en kötülerin değil en iyilerin çocuklarının yetiştirilmesi ve böylece cinsin bozulmaması gerektiği görüşünü taşır ki, ona göre bunun da yolu, kötülerin az ve iyilerin ise daha fazla çiftleşmesiyle gerçekleşebilir. ${ }^{53} \mathrm{Bu}$ görüşleriyle $\mathrm{o}$, transhümanizmin hedeflerinden olan modern öjeninin temellerini atmıştır.

Nitekim 20. yüzyılda üstün ırk Cermenleri yetiştirmek için insan haraları kuran Hitler, burada mavi gözlü, sarı saçlı Almanlarla kadınları çiftleștirerek, doğacak çocuklarla üstün Alman ırkını oluşturmak istemiştir. Yine 1933 yılında çıkardığı kanunla, sağlıklı insanları hastalardan ayırmış ve 74 bin akıl hastasını öldürmüştür. Aynı dönemde aşağı ulus ve ırktan sayılan 12 milyon insan da öldürülmüștür. ${ }^{54}$

Genetik mühendislik ve klonlama ile birlikte seçilmiş insanları transhumana dönüştürmek için kullanılan öjeni, doğuştan üstün canlılar meydana getirmek için 'insan ırkının ıslahı'nı hedef alır. ${ }^{55}$ İki dünya savaşı arasında öjeninin bıraktığı kötü izlere rağmen, günümüzde biyoteknolojinin de ilerlemesiyle, bu konu tekrar önem kazanmıştır. Bilimsel gelişmeler, öjeninin bir devlet politikası olma ihtimalini taşımaktadır. Nitekim Kanada, İskandinav ülkeleri, otuz ABD eyaleti ve Almanya, suçluların ve 'zekâ özürlüler'in istekleri dışında kısırlaştırılmasına izin vermiştir. ${ }^{56} 30$ yıldan fazla süredir Çin'in öjeni çalışmaları yaptığı, gelecek neslin IQ seviyelerini artıracak kimi çalışmalarda bulunduğu ve küresel rekabet yarışında Avrupa ile ABD’nin de Çin devletini örnek alması gerektiği yüksek sesle dile getirilmektedir. ${ }^{57}$

Transhümanistler, sentetik genler tasarlama ya da genlerin kontrol edilmesiyle insan değişiminin gerçekleşebileceği hatta balina ya da filin genleriyle insan

${ }^{52}$ Daniel J. Kevles, In The Name of Eugenics, Genetics and The Uses of Human Heredity (USA: University of California Press, 1985), X.

53 Platon, Devlet, çev. Sabahattin Eyüboğlu-M. Ali Cimgöz (İstanbul: İş Bankası Yayınları, 2010), 161162.

54 Necla Mora, Alman Kültüründe Düşman İmgesi (Altkitap, 2009), 29-30.

55 Dağ, "Hümanizmin Radikalleşmesi”, 59.

${ }^{56}$ Steven Pinker, Boş Sayfa, çev. Mehmet Doğan (İstanbul: Boğaziçi Üniversitesi Yayınevi, 2016), 32.

57 Abdurrahman Ali Yıldırım, Tıp Hukuku Bağlamında Insanı Geliștiren Biyoteknoloji Uygulamaları (İstanbul: Medeniyet Üniversitesi, Sosyal Bilimler Enstitüsü, Yüksek Lisans Tezi, 2019), 80-81. 
genlerinin zenginleştirilebileceğini düşünmektedir. Amerika'da 2004 yılında yapılan bir ankette, Amerikalıların yüzde 28'inin 'güç veya zekâ', yüzde 58'inin yetişkinlikte kansere yakalanmayı engellemek ve yüzde 68'inin de çocuklukta ölümcül hastalıklardan kaçınmak için embriyo seçilimini onayladığı ortaya çıkmıştır. ${ }^{58} 3$ Şubat 2015 yılında da İngiltere Parlementosu'nda "üç ebeveynli embriyo" adlı yasa geçmiş ve bu konuda uygulanacak olan tedavi ve araştırmaların önü açllmıştır. ${ }^{59}$

İnsanların kendi genetik özelliklerini belirleyebileceğini savunan transhümanistler, hamilelik süresi ve ergenlik zamanı gibi dönemlere de hâkim olabileceklerine inanmaktadırlar. Tüm bu düşüncelerin nedenini ise genetik kaynaklı hastalıkları yok etmek, daha sağlıklı nesillere sahip olmak ve insan ömrünü uzatmak oluşturmaktadır. ${ }^{60}$

Transhümanizmin önemli temsilcilerinden olan ve genetik bilimini kullanarak insanların daha üstün bir hâle dönüştürüleceğine inanan Haldane (18921964), hayatın kalitesini ve performansını daha da artırmak için sentetik gıdaların üretimini ve kimyasal maddelerin kullanımını savunurken61, Fukuyama (doğ. 1952) da bebeklerin tasarımlarının anne-babalarına bırakılmasının daha iyi olacağını ifade etmektedir. ${ }^{62}$

Öjeni, bir devlet veya devlet başkanının hoşlanmadığı bir halkın biyolojik yapısına müdahale etmesi, onları çocuk sahibi olmaya yüreklendirmesi veya çocuk yapma heveslerini kırması, kimi zaman bu kararı onların elinden alması ve kimi zaman da halkı doğrudan öldürerek müdahale etmesidir. ${ }^{63} \mathrm{Bu}$ anlamda tarihte öjeniyi -ilkel ve vahși şekilde- ilk uygulayanlardan biri, İsrailoğullarından bir çocuğun tahtına geçeceği endişesiyle İsrailoğullarının bütün erkek çocuklarını öldüren Firavun'dur.

Günümüzde tıp ve genetik mühendisliği alanındaki gelişmelerle gündemi işgal eden neslin ıslahı konusundaki çalışmalar, aslında insanlık tarihi kadar eskidir. İnsanoğlu her zaman daha üstün, daha güçlü ya da daha asil bir nesle sahip olmayı istemiştir. Örneğin Âişe, cahiliye dönemindeki nikâh çeşitlerinden bahsederken şöyle demiştir: "Bir diğer nikâh şekli şöyle idi: Erkek, temizlendiği zaman hanımına: "Soylulardan falana git, ondan seninle cinsel ilişkiye girmesini iste" derdi. Hanımını gönderdiği erkekten hamile kaldığı kesinleşinceye kadar ona dokunmazdı. Hanımının hamileliği belli olunca, dilerse kocası onunla ilișkide bulunurdu. Nikâhu'l-istibda adlı bu teklif, çocuğun asil bir kan taşıması için yapılırdı." 64

Beden ve ruh açısından insana büyük bir değer veren İslam, evlenmeyi teşvik ederken gelecek nesillerin de daha sağlıklı ve uygun ortamlarda yetişmelerini

\footnotetext{
${ }^{58}$ Nick Bostrom, Süper Zekâ, çev. Ferit Budak Aydar (İstanbul: Koç Üniversitesi Yayınları, 2020), 61-62.

${ }^{59}$ Yıldırım, Tıp Hukuku Bağlamında, 82.

60 Ahmet Dağ, "Yaratılışa Müdahale ve Yeni Bir Evrimci Neo-Darwinist Bir Yaklaşım Olarak Transhümanizm", FLSF 27 (2019), 165.

${ }^{61}$ Ahmet Dağ, Transhümanizm: Insanın ve Dünyanın Dönüşümü (Ankara: Elis Yayınları, 2018), 141.

${ }^{62}$ Francis Fukuyama, Insan Ötesi Geleceğimiz: Biyoteknoloji Devriminin Sonuçları, çev. Çiğdem Aksoy (Ankara: ODTÜ Geliştirme Vakfı Yayıncılık, 2003), 109.

63 Pinker, Boş Sayfa, 175.

${ }^{64}$ Buhârî, "Nikâh", 37.
} 
tavsiye etmiştir. Kuşkusuz hastalıkların yaygın olmadığı ve gıdaların sağlığa uygun olduğu aile ve ortamlarda yetişen nesiller, daha güçlü bir gelecek oluştururlar. Sağlıklı bir nesil için Arapların yeni doğan çocukları Mekke'nin ağır ve kötü havasından uzaklaştırmaları, fasih dili kaynağından öğrenmeleri ve salgın hastalıkların bulunmadığı yerlerde daha sağlıklı ve temiz bir ortamda yetişmeleri için sütannelere verme geleneği de bunun bir yansımasıdır. ${ }^{65} \mathrm{~Hz}$. Peygamber, Medine'de sütannesi Halime tarafından bakılmış, o da Mariye'den olan oğlu İbrahim'i sütannelik yapması için Ümmü Bürde'ye vermiştir. ${ }^{66}$ Arap toplumundaki bu gelenek İslam toplumunda da devam etmiş, ancak neslin daha iyi olması için gösterilen çaba, evlenmek için seçilen aday veya çocuğun yaşayacağı ortam ile sınırlandırılmış, doğum öncesi ya da anne rahminde herhangi bir müdahaleye izin verilmemiștir. $\mathrm{Hz}$. Peygamber, "Kadın ile şu dört özellik için evlenilir: Malı, asaleti, güzelliği ve dindarlığı için. Sen dindar olanı seç ki, bereket bulasın"67 ve "Dünyanın en hayırlı varlığı saliha bir kadındır"68 diyerek neslin daha iyi olmasının ancak Allah'ın rızasına uygun bir evlilik kurmakla mümkün olacağına, bunun yolunun da mütedeyyin bir kadınla evlenmekten geçtiğine ișaret etmiștir.

Tanrılık iddiasında bulunan transhümanizm, öjeni veya genler üzerinde modifikasyonlarla insanın daha mükemmel bir varlık hâlini kazanabileceğini iddia ederken, İslam'a göre kusursuz ve belli bir ölçü ile yaratılmıș dünya ve insanoğlunun ıslahı ${ }^{69}$, ancak fitratı korumakla mümkündür. ${ }^{70}$ İslam'a göre neslin islahı, dinin ve ahlâkın öncelik kazandığı aile kurumu ile bașlar. Örneğin Hz. Peygamber'in "Dininden ve ahlâkından hoşlandığınız biri sizden kız istemeye gelirse, verin! Vermezseniz, yeryüzünde fitne ve büyük bir bozgunculuk çıkar." 71 hadisi, bozgunculuk ya da yeryüzünde daha güzel bir yaşama ilişkin İslam'ın farklı bakış açısını yansıtır.

Diğer yandan transhümanizmin öjeni ile peșine düştüğü daha güçlü, daha zeki ve daha asil neslin aksine İslam'a göre en üstün ve değerli, en zeki ya da en güçlü olan ancak Allah'tan en çok korkup sakınandır. ${ }^{72}$ Zekâ ya da güç olsun, tüm insanî özellikler ancak Allah'a kulluğa vesile olması durumunda değerlidir ve bu anlamda İslam'ın bu niteliklere bakıșı da farklıdır. Örneğin güçlü ve kuvvetli olmak, transhümanizmin hedeflediği gibi beş yaşındaki bir çocuğun olimpiyat sporcusunun bedenine sahip olması ya da zeki kimsenin, karşısındaki yapay zekâya sahip bilgisayarları satrançta yenmesi değildir. İslam, sadece sahip olduğu kabiliyetlerle değil, Allah'a olan yakınlığıyla da insanı değerlendirir. Örneğin, "Kuvvetli kimse, gürește hasmını yenen pehlivan değil, öfkelendiği zaman nefsini yenen kimsedir."73

\footnotetext{
65 Âmâl Karâmî, el-İhtilâf fi's-sekâfeti'l-Arabiyyeti'l-İslamiyye: Dirâse cenderiyye (Tunus: Dâru'l-Medâri'lİslâmi, 2007), 117.

${ }^{66}$ Müslim, "Fedâil" 2316; Ebu Cafer b. Habib el-Bağdadî, el-Muhabber, thk. Elisa Lihten Schtaytr (Beyrut: Dâru'l-Âfâki'l-Cedide, 1431), 429.

${ }^{67}$ Buhârî, "Nikâh" 16; Müslim, "Radâ" 1466.

68 Müslim, "Radâ" 1467; Ebu Abdillah Muhammed b. Yezid b. Mâce, Sünen-i İbn Mâce, thk. Şuayb elArnaûd vd. (B.y.: Dâru'r-Risâleti'l-Âlemiyye, 2009), "Nikâh” 5.

${ }^{69}$ er-Ra'd 13/8; el-Kamer 54/49.

70 er-Rûm 30/30.

${ }^{71}$ Tirmizîl, "Nikâh" 3; İbn Mâce, "Nikâh" 46.

72 el-Hucurat 49/13.

${ }^{73}$ Buhârî, “Edeb” 76; Müslim, “Birr ve’s-Sıla” 2609.
} 
Ya da zeki kişi, sadece on basamaklı iki sayıyı zihninden çarpan değil, aynı zamanda "Zeki kimse kendisini hesaba çeken ve ölümden sonrası için çalışandır. Âciz kiși ise arzularına uyup bir de Allah'tan (bağışlanma) umandır." ${ }^{44} \mathrm{Bu}$ ve benzeri hadisler, güç ya da zekâ kabiliyetlerinin bilinen anlamını yadsımamakta, ancak transhümanizmin ihmal ettiği üzere bu kabiliyetlerin manevî bir yönünün olduğuna da işaret etmektedir. Dolayısıyla İslam'da 'daha güçlü, 'daha zeki' ve 'daha iyi' ifadeleri, sadece materyalist değil aynı zamanda dinî ve ahlâkî bir değerdir.

Hz. Peygamber'in evlenilecek kadına bakılmasını emretmesi ${ }^{75}$, taraflar arasında önceliğin 'gen eşitliği' değil sevgi ve muhabbete dayandırılması esası da neslin daha iyi olmasını sağlayacak unsurlardandır. İslam'da 'insan neslinin ıslahı' ya da daha doğru bir ifadeyle 'hayırlı nesil', dindar bir eșin tercih edilmesi ve eşlerin cinsel ilişkide bulunurken bile şeytandan Allah'a sığınmasıyla başlar. Müslümanların, hayırlı bir nesil için: "Ey Rabbimiz! Eşlerimizi ve çocuklarımızı bize göz aydınlığı kıl ve bizi Allah'a karşı gelmekten sakınanlara önder eyle"76 şeklinde dua etmeleri de, transhümanizmin fizyolojik ya da biyolojik açıdan üstün insan özlemi yerine, öncelikle iman ve takva sahibi bir neslin peşinde olduklarını gösterir.

İslam, neslin ıslahı konusunda transhümanizmin peşinde olduğu, daha zeki ya da güçlü çocuk sahibi olmak isteyenlere sperm bankaları aracılığıyla güzellik kraliçelerinin, dâhilerin ya da güçlü kimselerin spermlerinin satılıp suni döllenme yapılmasına karşıdır. Bunun yanında istenen özelliklere sahip kişiliklerin kopyalanmasına (klonlama), eşler arasındaki sevgi ve muhabbeti göz ardı ederek, bireyleri çiftleştirilmesi gereken hayvanlar seviyesinde değerlendiren genetik danışmanlıklara da karşıdır. ${ }^{77}$ Transhümanizmin 'daha zeki', 'daha güçlü', 'daha iyi' arzuları, İslam'ın 'daha' idealiyle çelişir. Her şeyin bir üstünü ifade eden 'daha' kelimesi, İslam'da ancak Allah'a yaklaştırdığı sürece makbuldür ve bunu karşılayan en güzel ifade 'hayırlı' kelimesidir.

Transhümanizmin başta kadın ve aile kurumu olmak üzere genleri ve bireyleri hedef alan tüm bu çalışmaları, " 0 , dönüp gitti mi (yahut bir iş başına geçti mi) yeryüzünde ortalığı fesada vermek ve ekinleri tahrip edip nesilleri bozmak için çalışır."78 âyetinde geçtiği üzere 'ekini ve nesli bozmak' olarak değerlendirilebilir. Nitekim müfessirlerden birçoğu, 'nesil' kelimesini 'insanoğlunun soyu'79 veya 'her dişiden çıkan yavru'80; 'ekin' kelimesini de "Kadınlarınız sizin için bir tarladır"81 âyetinin delâletiyle 'kadınlar' olarak açıklamıştır. ${ }^{82}$ Bunun yanı sıra ekini bozma işi,

\footnotetext{
74 İbn Mâce, "Zühd" 31; Tirmizî, "Kıyamet” 25.

75 Müslim, "Nikâh" 1424.

76 el-Furkan 25/74.

77 Merhaba, İsmail Ğazi, “Tahsinu'n-nesl (Eugenics)” Dirasetun Tıbbiyyetun Fıkhiyye (B.y.: y.y., trs.), 272.

78 el-Bakara 2/205.

${ }^{79}$ Ebu Cafer Muhammed b. Cerir et-Taberî, Câmiu'l-beyân an te'vil-i âyi'l-Kur'an (Mekke: Dâru't-Terbiye ve't-Turas, trs.), 4/240; Ebu Mansur Muhammed el-Maturidî, Te'vilatu ehli's-sünne, thk. Mecdi Bâslûm (Beyrut: Dâru'l-Kütübi'l-i̇lmiyye, 2005), 1/280.

${ }^{80}$ Ebu Abdillah Muhammed b. Ahmed el-Kurtûbî, el-Câmi' li ahkâmi'l-Kur'an, thk. Ahmed el-Berdûnî vd. (Kahire: Dâru'l-Kütübi'l-Misriyye, 1964), 3/17; Ebu'l-Ferec Abdurrahman b. Ali el-Cevzî, Zâdu'l-mesîr fî ilmi't-tefsir, thk. Abdurrezzak el-Mehdî (Beyrut: Dâru'l-Kütübi'l-Arabî, 1422), 1/171.

81 el-Bakara 2/223.

82 Taberî, Câmiu'l-beyân, 4/241; Maturidî, Te'vilatu ehli's-sünne, 2/101; Râzî, Mefâtihu'l-ğayb, 5/347;
} 
tarım ürünlerine yapılan müdahale ve nesli bozma işi de embriyolara yapılan genetik müdahale olarak değerlendirilebilir. Beslendiği gıdanın genetiğini değiștirerek onu zehirli bir GDO'ya çevirenler, genlere de müdahale etmeye kalkışmakta ve bunu yaparken de, tıpkı âyette geçtiği gibi, ıslahta bulunduklarını iddia etmektedir: "Kendilerine: "Yeryüzünde bozgunculuk yapmayın" denildiği zaman, "Bizler sadece sslah edicileriz" derler."83

Öjeni, kürtaj ve genetik bilimi ile insan ya da bitki olsun canlıların genlerine, kısaca Allah'ın yarattığı fitrata müdahale etmeye çalışan transhümanizm, şeytanî bir dünyanın inşası peşindedir. "Size rızık olarak verdiğimiz iyi ve temiz şeylerden yiyin ama bunda ölçüyü aşmayın"84 ilahî emri gereğince temiz ve helâl yiyeceklerle beslenmesi gereken nesil, hibrit tohumlarla yetişen bitkiler, sentetik ve suni yiyecekler, hazır gıdalarla zehirlenmekte, haram yiyecek ve içeceklerle fitratları ya da genetikleri değiştirilmektedir.

Kadın ve aile kurumu ile ilgili olarak transhümanizm, ilerleyen zamanlarda ortaya çıkartılması hedeflenen 'posthuman' türünde cinsiyet için bir sınır düşünmemekte, hatta cinsiyetler arası geçişlerin gerçekleşebileceği ve cinsiyeti olmayan cinsiyet üstü varlıkların ortaya çıkacağını ileri sürmektedir. 85 "Neden sıfır cinsiyet ya da sonsuz sayıda cinsiyet olmasın?" sorusunu soran transhümanizmin hedefinde, kadın ve aile kurumunu ortadan kaldırmak vardır. Kadın ve erkek cinsi yerine nötr bir cinsiyetten yana olan postcinsiyetçilik (postgenderizm) ${ }^{86}$ düşüncesi de, transhümanizmin hedefleri arasındadır. Bu akımın önde gelenlerinden Amerikalı feminist-akademisyen Haraway'a (doğ. 1944) göre kadınlar, ancak üreme yükümlülüklerinden vazgeçtiklerinde kurtulabileceklerdir. ${ }^{87}$ İkili cinsiyet anlayışının bireylerin ve toplumun zararına olup gelecekte insanların isterse biyoteknoloji yoluyla üreme teknolojileri kullanarak cinsiyetlerinden kurtulmayı seçmelerini öne süren akım, yapay rahimler yoluyla 'kadınları üreme biyolojilerinin zorbalığından' kurtarma söyleminde ${ }^{88}$ bulunmaktadır.

Allah, huzur bulmaları için insanlığı erkekler ve kadınlar şeklinde yaratmış, aralarında sevgi ve merhameti var etmiş, evlenmeyi ve nesil sahibi olmayı emretmişken, insanı sadece bedeniyle değerlendiren transhümanizm ise fitrata aykırı şekilde toplumsal cinsiyet eșitliğini ve yalnız yaşamayı empoze etmektedir. Maalesef anlık hız ve hazların peşinde olan nesiller, bu düşüncelerin etkisinde arzularının ve fitratlarının zıddına hareket etmeye, evliliği ilkel bir birliktelik şekli olarak

Ebu Muhammed Abdulhakk İbn Atiyye, el-Muharraru'l-veciz fi tefsir-i Kitabi'l-aziz, thk. Abdusselam Abduşşafi (Beyrut: Dâru'l-Kütübi'l-İlmiyye, 1422), 1/280.

83 el-Bakara 2/11.

84 Taha $20 / 81$.

85 İsmail Kurt, Transhümanizm ve Tekillik Bağlamında Dinin Geleceği (Konya: Necmettin Erbakan Üniversitesi, Sosyal Bilimler Enstitüsü, Yüksek Lisans Tezi, 2019), 27.

86 Postcinsiyetçilik (postgenderizm): Toplumsal cinsiyetin biyoteknoloji ve üreme teknolojilerindeki son gelişmeler sayesinde gönüllü olarak ortadan kaldırılmasını savunan toplumsal, siyasi ve kültürel bir harekettir. (Slavoj Zizek, Cinsel Olan Politik Midir?, çev. Bahadır Turan (İstanbul: Encore Yayınları, 2018), 68).

${ }^{87}$ Donna J. Haraway, Simians, Cyborgs and Women (New York: Routledge, 1991), 149-181.

88 Shulamith Firestone, Cinselliğin Diyalektiği, çev. Yurdanur Salman (İstanbul: Payel Yayınları, 1993), 19-21. 
görmeye başlamıştır. Yaşam ve ölüm hakkında söz sahibi olmaya çalışan transhümanizm, cinsiyet ayrımını kaldırmakla erkek ve kadının, yapay rahimler ve öjeniyle de doğacak nesillerin geleceğini tehlikeye atarak fitratı ortadan kaldırmaya çalışmaktadır.

\section{Modifikasyonlar: Allah'ın Yarattığını Değiștirme}

Transhümanizmin birçok iddiası, Allah'ın emir ve yasaklarına karşı bir düzen kurmaya, fıtratı ve yeryüzündeki dengeyi değiştirmeye çalışan şeytanın Kur'an'da geçen iddialarında görüldüğünden dolayı genel anlamda İslam ile transhümanizmin uzlaşma ihtimali yoktur. Transhümanizmin vaatleri ile şeytanın hedefleri arasında bir paralellik bulunduğu iddiasına bilimsel olmadığı yönünde itirazlar olabilir, ancak konuya zaten İslamî açıdan bakıldığı için bu şekilde değerlendirmekte bir sakınca yoktur. Nitekim tarih boyunca Allah'ın yarattığı düzene, fitrata ve kâinattaki dengeye karşı çıkan tüm hareketler İslam'a göre şeytanî bir yön taşır.

İnsanın ve dünyanın kusurlu șekilde yaratılmıș olduğunu ve bunun sorumlusunu Tanrı olarak görmeleri, doğal olarak çoğunluğunu ateist ve natüralistlerin oluşturduğu birçok transhümanistin şeytanı haklı görmesine ve bunu açıkça itiraf etmesine de neden olmuştur. Max More (doğ. 1964), "Şeytan (Lucifer), aklın, zekânın, eleştirel düşüncenin somutlaşmış halidir. Tanrı'nın dogmasına ve diğer tüm dogmalara karşı durur. Yeni fikirlerin keşfini temsil eder... Bana katılın, Şeytan’a katılın! Zihnimiz, irademiz ve cesaretimizle, Tanrı ve entropik güçlere karşı savaşa katılın!"89 der. 0, kör bir şekilde itaat etmekten kaçınan, takip edecek değerleri için karar verme yeteneğini elde etmek isteyen Âdem ve Havva'nın tek günahlarının, bilgi ağacının meyvesini yemek olduğunu, onlara bu ilhamı da 'ișık-getiren' Lucifer'in verdiğini ve semavî dinlerde yer alan Âdem ile Havva kıssasının sadece Tanrı'ya inananların bakış açısından anlatıldı̆̆ını söyler. Peki, gerçekten transhümanizmin ve şeytanın iddiaları arasında bir benzerlik var mıdır?

Kur'an'a göre şeytanın insana karşı mücadelesi yedi şekilde gerçekleşir. Bunlardan dördü, Nisa sûresinin 119. âyetinde ve diğer üçü de A'raf sûresinin 1617. âyetlerinde geçer. Şeytan, hidayetten dalâlete ve İslam'dan küfre sevk ederek, Allah'ın kullarından nasibini alacağını, "Onları mutlaka saptıracağım..."90 sözüyle belirtmiştir. İlk olarak Âdem'i itaatsizliğe sürüklemek için onu saptırmış, bu konuda başarıya ulaşınca insanoğlunu da aynı șekilde yoldan çıkaracağını, “...ben de onları saptırmak için senin doğru yolunun üstüne oturacă̆ım. Sonra (pusu kurup) onlara önlerinden, arkalarından, sağlarından ve sollarından sokulacağım..."91 âyetinde ifade etmiştir. Tarih boyunca da bu çabasını bir an olsun bırakmamıştır.

İkinci olarak şeytan, “...mutlaka onları kuruntulara sokacağım...” iddiasında bulunmuştur. Bununla kastedilen diriliş, cennet ve cehennemin olmadığı ${ }^{92}$, dünya-

\footnotetext{
${ }^{89}$ Max More, "In Praise of The Devil", Atheist Notes (London: Libertarin Alliance, 1991), 1-2.

${ }^{90}$ en-Nisa $4 / 119$.

${ }^{91}$ el-A'raf 7/16-17.

92 Ebu'l-Hasen Mukatil b. Süleyman, Tefsir-u Mukatil b. Süleyman, thk. Abdullah Mahmud Şehhate
} 
da tûl-u emel sahibi olup dünyayı âhirete tercih etme ${ }^{93}$, tevbeyi geciktirme ${ }^{94}$, şeytanın insanları Allah'a itaatten ve tevhidden uzaklaştırıp kendisine itaat etmeye çağırması veya insanları arzularına göre hareket etmelerini ${ }^{95}$ teșvik eden kuruntulardır. Transhümanizmin dünyayı cennete çevirme çabası, ölümsüzlük ve ihtiyarlığı geciktirme vaatleri de bu kuruntulardandır.

Yine cahiliye döneminde gerçekleșen, “...ve onlara emredeceğim de (putlara adak için) hayvanların kulaklarını yaracaklar..." ifadesi de şeytanın üçüncü vaadidir. Nitekim cahiliye Arapları bir diși deve beşinci kez doğurduğunda ve doğan yavru erkek olduğunda, o devenin kulaklarını yarar ve ondan faydalanmaya son verirlerdi. Onunla ne su taşır ve ne de meraya götürürlerdi. 0 deve ile karşılaşan insanlar da ona binmezdi. ${ }^{96}$ Şeytanın emriyle Arapların arasında yaygınlaşan bu gelenek, onların en saçma fiillerindendi. $\mathrm{Bu}$ hayvanlar, insanların kendilerinden faydalanması için yaratılmış olmasına rağmen, onlar bu faydadan kendilerini mahrum ederek Allah'ın yarattığı fitrata ve onun hükmüne karşı çıkıyorlardı. Oysa doğacak yavrunun erkek ya da dişi olmasında en ufak bir yetkileri bulunmuyordu. Buna rağmen şeytanın kendilerine yaptıklarını süslü/mantıklı gösterdiği bu saçma fiili bir inanç meselesi haline getirmişlerdi ki, bu da şeytanın sözünü yerine getirdiğini göstermektedir.

Dördüncü ve son olarak -transhümanizm, ölümsüz ya da kusursuz bir insan yaratacağını iddia etse de- şeytan dahi bir şey yaratamayacağının farkında olarak, insanlara sadece Allah'ın yarattığını değiștirmelerini emredeceğini şu sözüyle ifade etmiştir: "Yine onlara emredeceğim de Allah’ın yarattığını değiștirecekler."97 Âyette, 'Allah'ın yarattığını değiştirme' ifadesi ile neyin kastedildiği hakkında üç görüş vardir:

a. Sahabe, tabiîn ve klasik dönem müfessirlerinden bir topluluğa göre, 'Allah'ın yarattığını değiştirme' ile kastedilen 'Allah'ın dini'ni değiştirmektir. İbn Abbas (ö. 68/687-88), Said b. Müseyyeb (ö. 94/713), Said b. Cübeyr (ö. 94/713), İbrahim en-Nehâî (ö. 96/714), Mücahid (ö. 103/721), İkrime (ö. 105/723), Dahhâk (ö. 105/723), bir rivayete göre Hasan-ı Basrî (ö. 110/728), Katâde (ö. 117/735), Süddî (ö. 127/745), Atâ el-Horasanî (ö. 135/752), İbn Ebî Talha (ö. 143/760), Mukatil b. Süleyman (ö. 150/767), Süfyan-ı Sevrî (ö. 161/778) ve İbn Zeyd (ö. 182/798) bu görüştedir. ${ }^{98}$

(Beyrut: Dâru İhyâi't-Turâs, 1423), 1/408; Ebu Muhammed Huseyn b. Mes'ud el-Beğâvî, Meâlimu'ttenzîl fi tefsiri'l-Kur'an, thk. Abdurrezzak el-Mehdi (Beyrut: Dâru İhyâi't-Turâsi'l-Arabî, 1420), 1/703; İbnu'l-Cevzî, Zâdu'l-mesîr, 1/474.

93 Ebu'l-Hasen Ali b. Muhammed el-Maverdî, en-Nüketu ve'l-uyûn, thk. Seyyid b. Abdilmaksud (Beyrut: Dâru'l-Kütübi'l-İlmiyye, trs.), 1/530.

94 İbn Cevzî, Zâdu'l-mesir, 1/474.

${ }^{95}$ Beğâvî, Meâlimu't-tenzîl, 1/703.

96 Ebu İshak İbrahim b. es-Serî ez-Zeccâc, Meâni'l-Kur'an ve i'rabuh, thk. Abdulcelil Abde (Beyrut: Âlemu'l-Kütüb, 1988), 2/109-110.

97 en-Nisa 4/119.

98 Ebu'l-Haccac Mücahid b. Cebr, Tefsir-u Mücahid, thk. Dr. Muhammed Abdusselâm (Mısır: Dâru'lFikri'l-islamî, 1989), 292; Mukatil, Tefsir-u Mukatil, 1/408; Ebu Abdillah Süfyan b. Said es-Sevrî, Tefsiru's-Sevrî (Beyrut: Dâru'l-Kütübi'l-İlmiyye, 1983), 97; Taberî, Câmiu'l-beyân, 9/218-220; Ebu Muhammed Abdurrahman b. Ebi Hâtim, Tefsiru'l-Kur'ani'l-azîm, thk. Es'ad Muhammed et-Tayyib (S. 
b. Aralarında İbn Abbas, Rebi' b. Enes (ö. 53/673), İbn Ömer (ö. 73/693), Enes b. Malik (ö. 93/711-12), Şehr b. Havşeb (ö. 100/718), İkrime, Ebu Salih (ö. 101/719-20), Said b. Müseyyeb ve Sevrî'nin de bulunduğu diğer bir topluluğa göre de bu ifade ile kastedilen evcil/çiftlik hayvanlarını iğdiş etmek/kısırlaştırmaktır. ${ }^{99}$

c. Abdullah b. Mes'ud (ö. 32/652-53) ${ }^{100}$ ve Hasan-ı Basrî101 ise, bu ifadeyi dövme yaparak Allah'ın yarattığını değiștirmek olarak açıklamışlardır.

Tüm görüşler bir araya getirildiğinde, müfessirlerden bir bölümünün 'Allah'ın yarattığını değiștirme’yi manevî olarak Allah'ın dinini değiștirme ve bir bölümünün de âyette geçen 'hayvanların kulaklarını yaracaklar' ifadesinden dolayı insan ya da hayvan bedeni üzerinde gerçekleșen maddî bir değişiklikle açıkladıkları görülür. İlk bakışta birbirine zıt iki görüş olduğu izlenimi uyandırsa da aslında maddî değişikliğin de manevî değişikliğin kapsamında yer aldığı görülür.

Taberî (ö. 310/923), "Allah'ın yaratışında değişme yoktur; işte dosdoğru din budur, fakat insanların çoğu bilmezler."102 âyetinin delâletinden dolayı 'Allah'ın yarattığını değiştirme' ile kastedilenin Allah'ın dini olduğu görüşünü tercih etmiştir. ${ }^{103}$ Ona göre anlamın 'din' olması hâlinde iğdiş etme, dövme gibi Allah'ın yasaklamış olduğu tüm fiilleri yapmak ve Allah'ın emrettiği tüm fiilleri de terk etmek bu anlama dâhil olur. Çünkü şeytan, Allah'a isyan olan her șeye çağrıda bulunurken, O'na itaat olan her fiilden de alıkoyar. Böylelikle Allah'ın din olarak ortaya koyduğunu değiştirmekle insanlardan belirli bir pay alma iddiasını gerçekleștirmiş olur. 104

Zeccâc da (ö. 311/923), 'Allah'ın yarattığını değiștirme' ifadesini 'din' olarak açıklar. Ona göre, "Şeytan, kendilerine yaptıklarını süslü göstermiş..."105 olduğundan dolayı insanlar, binmeleri ve etlerinden faydalanmaları için yaratılan hayvanları kendilerine haram kılmış, güneş ve ayın yaratılış nedenini unutup onlara ibadet etmeye başlamış, böylece Allah'ın yarattığını yani dini değiştirmeye kalkışmışlardır. Oysa Allah, henüz Âdem'in sulbünde iken insanları İslam üzere yaratmış, Rableri olduğuna dair kendilerinden söz almıștır; bunu inkâr eden kimse, Allah'ın fitratını değiştirmeye kalkışmıştır. ${ }^{106}$

Dolayısıyla Taberî ve Zeccac'a göre kişinin kendi bedeni ya da hayvanlar üzerinde dilediği değișikliği yapabilme yetkisine sahip olduğuna inanıp buna göre fiilde bulunması, dinin emir ve yasaklarına uymamak anlamına geldiğinden, değiştirilmeye çalışılan şey Allah'ın dini olmaktadır. Nitekim 'Allah'ın yarattığını değiştirme' ifadesini fitrata aykırı tüm fiiller olarak açıklayan Vahidî’ye (ö. 468/1076)

Arabistan: Mektebetu Nizâr Mustafa, 1419), 4/1069; Ebu'l-Hasen Ali b. Ahmed el-Vahidî, el-Vasît fí tefsiri'l-Kur'ani'l-mecîd, thk. Âdil Ahmed vd. (Beyrut: Dâru'l-Kütübi'l-İlmiyye, 1994), 2/118; İbn Cevzî, Zâdu'l-mesîr, 1/474.

${ }_{99}$ Taberî, Câmiu'l-beyân, 9/215-217; İbn Ebî Hâtim, Tefsiru'l-Kur'ani'l-azîm, 4/1069.

100 Maverdî, en-Nüketu ve'l-uyûn, 1/530.

101 Taberî, Câmiu'l-beyân, 9/221; İbn Ebî Hâtim, Tefsiru'l-Kur'ani'l-azîm, 4/1069.

102 er-Rûm 30/30.

103 Taberî, Câmiu'l-beyân, 7/502.

104 Taberî, Câmiu'l-beyân, 9/222-223.

105 en-Neml 27/24.

106 Zeccâc, Meâni'l-Kur'an, 2/110.
} 
göre haramı helâl ve helâli de haram ile değiștirmek Allah'ın yarattığını değiștirmektir. Buna göre sakıncalı ya da yasaklanmış bir fiil işleyen, Allah’ın dinini değiştirmiş olur. ${ }^{107}$

Râzî (ö. 606/1210) ise buradaki 'değiştirme'nin zâhire taalluk eden tüm haller anlamına geldiğini söyler. Hadiste geçen peruk takan ve taktıran, dövme yapan ve yaptıran kadınların; Enes'ten nakledilen koçların iğdiş edilmesi; İbn Zeyd'den nakledilen erkeğe benzemeye çalıșan kadın ve kadına benzemeye çalıșan erkeğin bu kapsamda yer aldığını belirtir. Şeytanın, karıştırma, eksiltme ve bozma yoluyla bir şeye müdahale edeceğini söyler. ${ }^{108}$

Hemen hemen bütün müfessirler 'Allah'ın yarattığını değiștirme' ile kastedilenin 'Allah'ın dini' olduğu konusunda ittifak etmiş olmalarına rağmen, ikinci bir görüş olarak saç ekleme ve cinsel açıdan erkeklerin erkeklerle, kadınların da kadınlarla birlikte olmayı tercih etmesi ${ }^{109}$, nesepleri karıştırma ya da yasaklandığı halde saçları siyaha boyamak ${ }^{110}$, köleleri iğdiş etmek, dövme yaptırmak, dişleri törpülemek, âzâları ve güçleri, nefse herhangi bir kemâl kazandırmayan ve Allah'a yakınlığa vesile olmayan yerlerde kullanmak ${ }^{111}$ gibi bedensel değişikliklere de işaret ettiğini açıklamışlardır.

'Allah'ın yarattığını değiștirme' ifadesinin maddî bir değișim olarak açıklanmasının nedeni, bedende estetik adına yapılan zahirî değișikliklerle ilgili İbn Mes'ud'dan nakledilen rivayettir. ${ }^{112}$ Rivayete göre Abdullah b. Mes'ud'un, "Allah, dövme yaptıran ve yapanları, güzellik için ön dişlerinin arasını açanları, tüylerini yolduranları ve Allah'ın yaratmış olduğu yaratılıșı değiştirenleri lanetlemiștir" sözü, Ümmü Yakub denilen Esed kabilesinden bir kadına ulaşınca: “Ey Ebu Abdurrahman! Bana, şunu şunu lanetlediğin haberi geldi" dedi. Bunun üzerine Abdullah: "Rasûlullah'ın (sav) lanetlemiş olduğunu ve Allah'ın Kitabı'nda mevcut olan şeyi niye lanetlemeyeyim ki?" cevabını verdi. Kadın: "Ben iki kapak arasını okumaktayım ve öyle bir şey görmemekteyim" deyince: "Eğer okumuş olsaydın görürdün. Sen: "Peygamber size ne verdiyse onu alın, size ne yasakladiysa ondan da saklnın"113 âyetini okumadın mı?" dedi. Kadın: "Evet, okudum" deyince: "Rasûlullah (sav) bunları yasakladı" dedi. Kadın: "Senin hanımın da bunlardan bazılarını yapmaktadır" deyince, Abdullah: "Git ve bak bakalım, öyle bir şey yapıyor mu?" dedi. Kadın gidip baktığında öyle bir şey olmadığını gördü ve gelip: "Böyle bir şey görmedim" dedi. Bunun üzerine Abdullah: "Eğer öyle bir şey olsaydı, o yanımızda bu-

\footnotetext{
107 Vahidî, el-Vasît fî tefsiri'l-Kur'an, 2/118.

108 Râzî, Mefatihu'l-ğayb, 11/223.

109 Şemsuddin Muhammed Hatib eș-Şirbînî, es-Sirâcu'l-münîr (Kahire: Matbaatu Bûlak, 1285), 1/333.

110 Ebu'l-Muzaffer Mansûr b. Muhammed es-Sem'anî, Tefsiru'l-Kur'an, thk. Yasir b. İbrahim (Riyad: Dâru'l-Vatan, 1997), 1/481.

111 Nasıruddin Ebu Said el-Beydâvî, Envâru't-tenzîl ve esraru't-te'vil, thk. Muhammed Abdurrahman elMar'aşlî (Beyrut: Dâru İhyâi't-Turâsi'l-Arabî, 1418), 2/98.

112 Maverdî, en-Nüketu ve'l-uyûn, 1/530; Beğâvî, Meâlimu't-tenzîl, 5/57; İbn Atiyye, el-Muharraru'l-vecîz, 2/114; Kurtûbî, el-Câmi' li ahkâmi'l-Kur'an, 5/392; Ebu'l-Fida İsmail b. Kesir, Tefsiru'l-Kur'ani'l-azîm, thk. Muhammed Huseyn Şemsuddin (Beyrut: Dâru'l-Kütübi'l-İlmiyye, 1419), 2/367.

113 el-Haşr 53/7.
} 
lunamazdı" dedi.114

Çağdaş müfessirlerden İbn Âşûr (ö. 1973), hadislerde geçen güzellik için saç ekleme ya da dişlerin arasını ayırma gibi fiillerin yasaklanmasının te'vilinde müşkil olduğunu söyler. Ona göre bunların yasaklanmasının nedeni, o dönemde ahlâksız ya da müşrik kadınların bu fiillerde bulunmasıdır. Yasaklanmış olsa bile, bunun laneti hak edecek bir seviyeye ulaşamayacağını belirten İbn Âşûr, âyetin bağlamı dikkate alındığında bu fiillerin ancak șeytana itaat kapsamına girmesi durumunda bir günah olacağını belirtir. ${ }^{115}$ Bu görüşün doğru kabul edilmesi hâlinde, insanların söz konusu filleri şeytana itaat için yapıp yapmadıklarını sorgulamak gerekir ki, bunun da kapsamına aslında tüm fiiller girer (haç takmak, zünnar bağlamak gibi). Bu durum ise İslam'ın zâhire göre hükmettiği ilkesini ortadan kaldıracağı gibi Hz. Peygamber'in aslında din bağlamında değerlendirilmesi gereken bedenle ilgili konularda teşrîde bulunamayacağı ve sakıncalı fiilleri işleyenleri lanetleyemeyeceği gibi yanlış bir inancı zihinlere düşürür.

Oysa bu fiillerin laneti hak etmesi konusunda mütekaddim müfessirler arasında herhangi bir problem yoktur. Müfessirlerin, 'Allah'ın yarattığını değiștirme' ile kastedilenin 'Allah'ın dinini değiștirmek' olduğunu ifade ederken bu rivayeti nakletmeleri, insan veya hayvan bedeni üzerinde gerçekleştirilen değişikliklerin de 'din' kapsamına girdiğini gösterir. Buna göre 'Allah'ın yarattığını değiştirme' ifadesi, hem maddî ve hem de manevî değişimin her ikisine de şamildir. Öte yandan merhamet sahibi olan Allah'ın ve Rasûlü'nün emrettiklerini yerine getirmenin rahmete, lanetlenmiş şeytanın fiillerini işlemenin de lanete neden olmasında anlaşılmayacak bir durum yoktur.

Rivayette söz konusu fiilleri yapanların Allah'ın yarattığını değiștirdiği ve laneti hak ettiğine dair açıklama İbn Mes'ud'a ait olup merfû bir hadis değildir. Bununla birlikte birçok müfessir, âyetin tefsirinde bu rivayeti nakletmiştir ki, bu da fitratın Yahudileşme veya Hristiyanlaşma yoluyla değiştirilmesinin manevî/dinî bir değișim iken, beden üzerinde dinin emir vermediği değişiklikleri yapmanın ise maddî bir değişim olarak kabul edildiğini gösterir. Böylece şeytan, maddî ve manevî her iki değişimi de gerçekleştireceğini iddia etmiştir. Birincisi, Allah'ın, insanları üzerinde yarattığı temiz fitratı ve imanı küfür ile değiștirme, diğeri ise güzel sûretleri yarmak, kesmek ve değiștirme yoluyla onları değiștirmedir. Böylece İslam fıtratını şirk ve bedenleri de müdahalelerle değiștirmiş olmaktadır.

Muhammed Abduh (ö. 1905) ise, hadiste geçen bu ağır ifadelerin sebebini Arapların bu konuda aşırıya kaçmaları olarak yorumlar. Dişlerin törpülenerek ayrılmasını, insan bedenini çirkin kılmayan bir değişiklik olarak değerlendirir ve bu fiili, saç ile tırnak kesmeye benzetir. Ona göre kınamayı hak eden zahirî değişiklikler, tahrif etme ve șekil bozma nitelikli değişikliklerdir. ${ }^{116}$ Oysa Abduh'un burada değişiklikleri insan bedenini çirkin kılan ve kılmayan diye ikiye ayırması tamamen

114 Ahmed b. Hanbel, el-Müsned, 4/152; Buhârî, "Tefsiru'l-Kur'an” 147; "Libas" 164; Müslim, "Libas" 2125.

115 İbn Âșûr, Muhammed et-Tahir, et-Tahrir ve't-tenvîr (Tunus: Dâru't-Tûnisiyye, 1984), 5/205.

116 Reşid Rıza, Tefsiru'l-menâr (el-Hey'etu'l-Mısriyye, 1990), 5/350. 
göreceli ve önü alınamayacak bir husustur. Öte yandan bu tür bir değişimi, Hz. Peygamber'in "On şey fitrattandır"117 hadisinde geçen saç ile tırnak kesmeye benzetmesi, hadisin bağlamına girmediği gibi izahtan da vârestedir.

Allah'ın yarattığını değiștirme, bedende kalıcı iz bırakan değișikliklerle de sınırlı değildir. Bunun kapsamına Allah'ın din olarak ortaya koymuş olduğu tüm emir ve yasakların aksini yapmak da girer. Rağıb el-İsfehanî (ö. V./XI. yüzyılın ilk çeyreği), tüm bu zikredilenleri şöyle özetler: “Bu ifadede, Allah'ın yarattığı her şeyi mükemmel yaptığına ve insanın ise, şeytanın yanlış yönlendirmesiyle mükemmel olanı eksik kıldığına bir işaret vardır. Bunun nedeni, insanın sahip olduğu bir güçle yaratılmış olmasıdır. Allah ona, nefsini ve içine işleyen şeyleri tezkiye etmesi için eğitmişken, o aşağılık bir hâle gelmiştir. Allah'ın yarattığını değiștirme, Allah'ın fazilet olarak var ettiği her şeyi, insanın ahlâksız bir şey için kullanması ve onun yaratılıș amacını değiștirmesidir. Bunun kapsamına, Allah'ın insana bahșetmiș olduğu ve üreme için neden kıldığı cinsel ilişki arzusu da girer. Ancak insan bu dürtüyü, evlilik dışı cinsel ilişki ve livata için kullanmaya kalkmıştır. İşte bu, Allah'ın yarattığı şeyi değiștirmektir. Kadınsı hareketlerde bulunan bir erkeğin sakalını koparması ve kadın kılığına girmesi, genç bir kızın erkekleri taklit ederek onlara benzemeye çalışması da bu kapsamdadır. Allah'ın helâl kıldıklarını haram ve haram kıldıklarını helâl kılmak da bu anlamdadır."118

Transhümanizmin ayak sesleri olarak değerlendirebileceğimiz, günümüzde müslümanların arasında estetik ameliyatlar ve zarurî olmayan cerrahi operasyonların gittikçe artması, rivayette geçen kadının söyleminin yaygınlaştığını göstermektedir. Naklettiğimiz rivayette 'Kur'an bize yeter' anlayışının tipik bir yansıması olarak değerlendirebileceğimiz bu tutumda kadın, Kur'an'da yer almadığından dolayı yasağa karşı çıkmakta, İbn Mes'ud ise Hz. Peygamber'in (sav) emredip yasakladığı hususların yani sünnetin de din olduğu yönünde ona hatırlatmada bulunmaktadır. Onun bu açıklaması, özellikle transhümanizm tehlikesi karşısında duruşumuzu şekillendirecek hususların Kur'an'dan ziyade sünnette yer aldığı gerçeğini de vurgulamaktadır. Hayatın her alanına karışan bir dinin varlığına rağmen, 'Kur'an'da geçmiyor' iddiasıyla sadece Kur'an ile yetinip sünnete karşı müstağni olmak, müslümanları yaklaşmakta olan tehlike karşısında çaresiz bırakacak ya da şeytanın söyleminin yayılmasına neden olacaktır. Bu noktada özellikle hadislerde yer alan süslenme ve güzellik ile ilgili sakıncalı hususların mütalaa edilip kriter olarak kabul edilmesi, müslümanların transhümanizm tehlikesine karşı savunma hattını oluşturacaktır.

Transhümanizmin süslü bir şekilde kulağa fısıldadığı, modifikasyonlarla sürekli genç ve güzel kalma ve bu amaçla bedene müdahale etme tarih boyu varlığını korumuştur. Kalp ve ruh güzelliğini bir kenara koyup insana bir nesne olarak ba-

${ }^{117}$ Hz. Peygamber şöyle buyurmuştur: “On şey fitrattandır: Bıyığın kesilmesi, sakalın uzatılması, misvak kullanmak, istinşak ve mazmaza yapmak, tırnakları kesmek, parmak mafsallarını yıkama, koltuk altını yolmak, etek traşı olmak ve istinca yapmak." Ahmed b. Hanbel, el-Müsned, 41/507; Müslim, "Taharet" 261.

118 Ebu'l-Kasım Huseyn b. Muhammed el-İsfehânî, Tefsiru'r-Râğıb el-ísfefehânî, thk. Hind binti Muhammed (Câmiatu Ümmi'l-Kurâ, 2001), 4/164. 
kan transhümanizm, 'bedenim bana aittir' söylemi üzerinden zihinleri işgal etmiştir. Güzelliğin geçici olduğu kuralına karşı çıkılırken, bilim ve teknolojinin ortaya koyduğu tüm gelişmelerden faydalanılarak gösterilen ideal bedenlere sahip olma yarışı hızla sürdürülmektedir. Sağlık ya da zarurî durumlarda uygulanması gereken ve tıp ilminin bir kolu olan estetik, güzellik merkezlerinin geçim kaynağı olmuş durumdadır. Kalbini modern dünyanın çalkantılarına kaptırmış müslüman da, günümüzde kalbini mutmain kılacak amellerden ziyade seküler hazların peșine düşmüş, güzelliğinin kalıcı olması için çaba göstermektedir. Oysa, "Allah sizin dış görünüşünüze ve mallarınıza bakmaz; kalplerinize ve amellerinize bakar."119

Özellikle estetik ameliyatlarla artık yaşlılık, engellilik durumu gibi algılanmakta, yüzde oluşan her kırıșıklığı gidermek için tıbbın imkânlarından faydalanılmakta, erkek ve kadın bedeni, kapitalizmin istediği ölçülerde yeniden kurgulanmaktadır. Genetikten fizikî görüntüye, genetiğiyle oynanmış yiyeceklerden ömrü uzatmaya kadar transhümanizmin tüm çabaları, aslında dünyanın ebedî olabileceği kanaatini insanlarda uyandırmaktır. 'Allah'ın yarattığını değiştirme' iddiasındaki şeytan, DNA'ların ve genlerin peşine düşmüştür. Kristal çocuklar ya da erkenden büyüyüp hızlı bir şekilde yaşlanan 'indigo'lar da bunun bir örneğidir.

\section{Sonuç}

İnsanın ve dünyanın dönüşümünü hedefleyen transhümanizm, şeytan ile dostları tarafından kâinatın eşsiz dengesine ve insan fitratına gerçekleştirilen saldırıların bütünü ya da insanın asıl yurdu olan cennete ulaşmasını engelleyip bu dünyada sahte bir cennet vaat eden ve insana bu cennetin Tanrısı rolünü veren yeni bir din olarak ifade edilebilir. İnsanlığın atası olan Âdem'e, kusursuz bir hayat olan cennette ebedî kalabilmesi ve melekleșebilmesi için yasak ağaca yaklaşmasını fısıldayarak onu kandırmış olan şeytan, şimdi de dünya yolculuğumuz sırasında altında sadece gölgelenmemiz gereken ağaca sımsıkı sarılmamızı tüm iletişim araçlarıyla haykırmaktadır.

Ne şekilde tarif edilirse edilsin, transhümanizm aslında insanlığa karşı şeytanın planlarının sadece güncellenmiş hâli ve insana secde etmeyen İblis'in, transhümanizmin vaatleriyle insanlığı kendisine secde ettirmeye kalkışmasıdır. İnsanı topraktan ve fitrattan ayıran, dünyanın dengesini değiştirmeye çalışan bu din, yapay rahimlerden üstün ırkı ortaya çıkarmanın peşindedir. Ölümsüzlük, yaşlanmayı geciktirme, öjeni ve Allah'ın yarattığını değiştirme iddialarıyla tamamen dünyevîliğin peşinde olan transhümanizm, elde ettiği baş döndürücü teknolojik ve tıbbî gelişmeler sayesinde, günümüzde müslümanların zihinlerinde de birtakım şüphelere neden olmakta, Allah'ın kadir-i mutlak olup her şeyi bir kader üzere yarattığı ve insan bedeninin bir emanet olduğu inancını zayıflatmaktadır.

İnsanın teknolojiden uzak kalması mümkün olmadığı gibi İslam da, bilim ve teknolojik gelişmelere karşı değildir. Allah'ın yarattığı fitrata ve vahyin öğretilerine uygun olan gelişmeler tasvip edilirken, insan bedeni üzerinde zarurî olmadığı hal-

119 Müslim, “Birr” 2564; İbn Mâce, “Zühd” 9. 
de kalıcı değişiklikler yapılmasına, tabiattaki dengeyi bozduğu halde insan yaşamını kolaylaştıran gelişmelere pragmatist bir bakıș açısıyla izin verilmez. Çünkü meleklerin haklı olarak itiraz ettiği gibi bilgi, hikmetten ve vahiyden ayrıldığı zaman yeryüzünde fesada neden olur.

Her şeyin fâni olduğu ve bâkî olanın Allah olacağı, klyametin ve âhiretin kesinlikle gerçekleșeceği İslam dininin temel inanç ilkelerindendir. Ömrün uzun ya da kısa olması da tamamen Allah'ın takdirine bağlı olup kader inancının bir tecellisidir. Neslin ıslahı ve Allah'ın yarattığını değiștirme konusunda da, -sağlık ve zarurî durumlar dışında- insana ne genlere ve ne de DNA'lara müdahale etme hakkı tanınmamıștır. İnsana düşen, Allah'ın yarattığı şekilde fitratı ve dünyadaki dengeyi bozmadan yaratılış amacına uygun şekilde hayat serüvenini tamamlamak, fitrat ve dengeyi korumaktır.

Diğer beşerî düşünceler ve ideolojilerle karşılaştırıldığında, belki de transhümanizm insanlığın ortaya attığı en tehlikeli fikirlerden biridir. Çünkü ilk kez insanlık, șeytanın Allah'ın yarattığını değiştirme söylemini dahi aşarak yaratıcılık iddiasında bulunmuştur. Bu fikrin asıl tehlikesi ise dile getirdiklerinin yapılabileceğine olan inanç değil, özellikle genç nesillerin dimağlarına bıraktığı şüpheler ve oluşturduğu iman zaafıdır. İnsanoğlu henüz kansere dahi çözüm bulamamış iken, transhümanistlerin dünyaya ve insana daha mükemmel bir yaşam sunabileceklerini iddia etmeleri ancak bir azgınlıkla nitelendirilebilir. Robotları bile hâlâ kusurlu kabul ettikleri insana benzetmeye çalışmaları, bir yandan onların taklitçiliklerini diğer yandan onların yaşam ve ölüm konusunda kendilerine itaat edilmesi gereken sahte tanrı olma çabalarını göstermektedir.

Teknolojinin, tıbbın ve bilimin insanlığı dönüştürmeye çalışan transhümanizm gibi bir güce dönüşmemesi ve fitrata uygun bir halde ilerlemesi için Kur'an ve sünnette yer alan ilkelere göre İslamî bir tavır ortaya konulmalı, yeni gelişmelere ve ilerlemelere karşı İslam'ın cevabı verilmelidir. Aksi halde şimdiden cep telefonu, tablet ve bilgisayar bağımlılığıyla ya da üzerinde taşıdığı teknolojik aygitlarla (i-watch, Google glass vs.) insanlığın yeni tapınakları teknomarketlerin önünde yarı cyborga dönüşmüş neslin transhümanist derneklere üye olmaları ve bu vaatlerin peşinde koşturmaları, dünyada var oluş amaçlarından saparak sahte güçlere hizmet eden bireylere dönüşmeleri ve yakın bir zamanda 'Bir hologram ile evlenmek caiz midir?' șeklinde tuhaf sorular sormaları şaşırtıcı olmayacaktır. Bu nedenle henüz İslam dünyasının çok tepki vermediği ve gündemini yeterince işgal etmediği bu harekete karşı, karşılaşacağımız muhtemel problemler için acilen bir fıkıh olușturulması gerekmektedir ki, bu konuda en büyük sorumluluk fikıh, hadis ya da din eğitimi alanları olsun, İlahiyat fakültelerindeki akademisyenlere düşmektedir. Aksi halde bedenlerde ve inançlarda başlayan bu dönüşümün önü alınamayacak ve geri dönüşü mümkün olmayan sonuçlarla karşılaşmamıza neden olacaktir.

Sonuç olarak teknolojik ve bilimsel gelişmeler sayesinde insanın seviye atlayıp artık 'İnsan 2.0' olarak nitelendirilmesi gerektiğini söyleyenlerin bilmesi gereken tek gerçek şudur: Tarih boyunca endişeleri, korkuları, ümitleri ve arzuları açısından ilk insan ile günümüzdeki insan arasında hiçbir fark yoktur. Ancak günü- 
müzde transhümanizmin vaatlerini insanın kulağına fısıldayan ve müslümanlara karşı komplolarını güncelleyen şeytan, teknoloji ile birlikte artık 'Şeytan 2.0' versiyonuna geçmiştir.

Funding / Finansman: This research received no external funding. / Bu araştırma herhangi bir diş fon almamıștır.

Conflicts of Interest / Çıkar Çatışması: The author declare no conflict of interest. / Yazar, herhangi bir çıkar çatışması olmadığını beyan eder.

\section{Kaynakça}

Ahmed b. Hanbel, Ebu Abdillah Ahmed b. Muhammed. el-Müsned. thk. Şuayb el-Arnaûd. 45 Cilt. b.y.: Müessesetu'r-Risale, 2001.

Beğâvî, Ebu Muhammed Huseyn. Meâlimu't-tenzil fî tefsiri'l-Kur'an. thk. Abdurrezzak elMehdi. 5 Cilt. Beyrut: Dâru İhyai't-Turâsi'l-Arabi, 1420.

Beydâvî, Nasıruddin Ebu Said. Envâru't-tenzîl ve esraru't-te'vil. thk. Muhammed Abdurrahman el-Mar'aşlî. 5 Cilt. Beyrut: Dâru İhyâi't-Turâsi'l-Arabî, 1418.

Beyhâkî, Ahmed b. Huseyn. el-Kadâ ve'l-kader. thk. Muhammed b. Abdillah. Riyad: Mektebetu'l-Ubeykân, 2000.

Bostrom, Nick. "A History of Transhumanist Thought". Journal of Evolution and Technology 14/1 (2005), 1-30.

Bostrom, Nick. Süper Zekâ. çev. Ferit Budak Aydar. İstanbul: Koç Üniversitesi Yayınları, 2020.

Bostrom, Nick. "Transhumanist Values, Ethical Issues for the 21st Century". Review of Contemporary Philosophy 4 (May 2005), 1-12.

Braidotti, Rosi. Insan Sonrası. İstanbul: Kolektif Kitap, 2013.

Buhârî, Muhammed b. İsmail. Sahihu'l-Buhârî. thk. Muhammed Zuheyr. 9 Cilt. B.y.: Dâru Tavki'n-Necât, 1422.

Dağ, Ahmet. "Hümanizmin Radikalleșmesi Olarak Transhümanizm”. Felsefí Düşün 9 (Ekim 2017), 46-68.

Dağ, Ahmet. Transhümanizm: İnsanın ve Dünyanın Dönüşümü. Ankara: Elis Yayınları, 2018.

Dağ, Ahmet. "Yaratılışa Müdahale ve Yeni Bir Evrimci Neo-Darwinist Bir Yaklaşım Olarak Transhümanizm", FLSF 27 (2019),153-168.

Demir, Aysel. "Ölümsüzlük ve Yapay Zekâ Bağlamında Transhümanizm". Online Academic Journal of Information Technology 9/30 (2018), 95-104. doi: 10.5824/1309-1581.2018.1.006.x

Edgar, Andrew. "The Hermeneutic Challenge of Genetic Engineering: Habermas and the Transhumanists". Medical Health Care Philosophy 12(2) (June 2009), 157-67. doi: 10.1007/s11019-009-9188-9

Firestone, Shulamith. Cinselliğin Diyalektiği. çev. Yurdanur Salman. İstanbul: Payel Yayınları, 1993.

Fukuyama, Francis. İnsan Ötesi Geleceğimiz: Biyoteknoloji Devriminin Sonuçları. çev. Çiğdem Aksoy. Ankara: ODTÜ Geliștirme Vakfı Yayıncılık, 2003.

Goldberg, Steven. "Does The Wall Still Stand? The Implications Of Transhumanism For The Separation Of Church And State". Georgetown Public Law Research Paper 09-10 (2009), 1-7.

Hans-Jörg Kreowski. "Transhumanism and Nanotechnology-Will Old Myths Come True?". Proceedings 1 (June 2017), 1-3. doi:10.3390/IS4SI-2017-03965

Harari, Yuval Noah. Homo Deus Yarının Kısa Bir Tarihi. İstanbul: Kolektif Kitap, 2016.

Haraway, Donna J. Simians, Cyborgs and Women. New York: Routledge, 1991.

Harrison, Peter- Wolyniak, Joseph. The History of 'Transhumanism', Notes and Queries 62/3 (September 2015), 465-467. https://doi.org/10.1093/notesj/gjv080 
Hava Tirosh-Samuelson, Kenneth L. Lossman. Building Better Humans: Refocusing the Debate on Transhumanism. Frankfurt: Peter Lang, 2011.

Hughes, James J., "The Politics of Transhumanism and the Techno-Millenial Imagination 1626-2030". Zygon 47/4 (December 2012), 760-768. doi.org/10.1111/j.14679744.2012.01289.x

İbn Âșûr, Muhammed et-Tahir, et-Tahrir ve't-tenvîr. 30 Cilt. Tunus: Dâru't-Tûnisiyye, 1984.

İbn Atiyye, Ebu Muhammed Abdulhakk. el-Muharraru'l-vecîz fî tefsir-i Kitâbi'l-aziz. thk. Abdusselam Abduşşâfî. 6 Cilt. Beyrut: Dâru'l-Kütübi'l-İlmiyye, 1422.

İbn Ebî Hâtim, Ebu Muhammed Abdurrahman. Tefsiru'l-Kur'ani'l-azîm. thk. Es'ad Muhammed et-Tayyib. 13 Cilt. S. Arabistan: Mektebetu Nizâr Mustafa, 1419.

İbn Habib, Ebu Cafer el-Bağdadî. el-Muhabber. thk. Elisa Lihten Schtaytr. Beyrut: Dâru'lÂfâki'l-Cedîde, 1431.

İbn Kesir, Ebu'l-Fida İmaduddin. Tefsiru'l-Kur'ani'l-azîm. 9 Cilt. thk. Muhammed Huseyn Şemsuddin. Beyrut: Dâru'l-Kütübi'l-İlmiyye, 1419.

İbn Mâce, Ebu Abdillah Muhammed b. Yezid. Sünen-i İbn Mâce. thk. Şuayb el-Arnaûd vd. 5 Cilt. Dâru'r-Risâleti'l-Âlemiyye, 2009.

İbnu'l-Cevzî, Ebu'l-Ferec Abdurrahman. Zâdu'l-mesîr fî ilmi't-tefsir. thk. Abdurrezzak elMehdî. 4 Cilt. Beyrut: Dâru'l-Kütübi'l-Arabî, 1422.

Kaku, Michio. Geleceğin Fiziği. Ankara: ODTÜ Yayıncılık, 2016.

Kaku, Michio. Zihnin Geleceği. Ankara: ODTÜ Yayıncılık, 2014.

Karâmî, Âmâl. el-İhtilâf fi's-sekâfeti'l-Arabiyyeti'l-İslamiyye: Dirâse Cenderiyye. Tunus: Dârü'lMedâri'l-İslâmi, 2007.

Kevles, Daniel J. In The Name of Eugenics, Genetics and The Uses of Human Heredity. USA: University of California Press, 1985.

Kur'an-ı Kerim Meâli. çev. Hayrettin Karaman-Mustafa Çağrıcı vd. Ankara: Diyanet İşleri Başkanlığı Yayınları, 3. Basım, 2017.

Kurt, İsmail. Transhümanizm ve Tekillik Bağlamında Dinin Geleceği. Konya: Necmettin Erbakan Üniversitesi, Sosyal Bilimler Enstitüsü, Yüksek Lisans Tezi, 2019.

Kurtûbî, Ebu Abdillah Muhammed b. Ahmed. el-Câmi' li ahkâmi'l-Kur'an. thk. Ahmed elBerdûnî vd. 10 Cilt. Kahire: Dâru'l-Kütübi'l-Mısriyye, 1964.

Kurzweil, Ray. Inssanlık 2.0. çev. Mine Șengel. İstanbul: Alfa Yayınları, 2016.

Maturidî, Ebu Mansur Muhammed. Te'vilatu ehli's-sünne. thk. Mecdi Bâslûm. 10 Cilt. Beyrut: Dâru'l-Kütübi'l-İlmiyye, 2005.

Maverdî, Ebu'l-Hasen Ali. en-Nüketu ve'l-uyûn. thk. Seyyid b. Abdilmaksud. 6 Cilt. Beyrut: Dâru'l-Kütübi'l-İlmiyye, trs.

Merhaba, İsmail Ğazi. “Tahsînu'n-nesl (Eugenics). Dirasetun Tıbbiyyetun Fıkhiyye”. Hawliyat Kulliyat Daru'l-Ulûm, al-Qahirah (2012), 249-296.

Mora, Necla. Alman Kültüründe Düşman İmgesi. b.y.: Altkitap, 2009.

More, Max. "In Praise of The Devil". Atheist Notes. London: Libertarin Alliance, 1991.

Mukatil b. Süleyman, Ebu'l-Hasen. Tefsir-u Mukatil b. Süleyman. thk. Abdullah Şehhâte. 5 Cilt. Beyrut: Dâru İhyâi't-Turâs, 1423.

Mücahid b. Cebr, Ebu'l-Haccâc. Tefsir-u Mücahid. thk. Dr. Muhammed Abdusselâm. Mısır: Dâru'l-Fikri'l-İslâmî, 1989.

Müslim, Ebu'l-Huseyn Haccac el-Kușeyrî. Sahih-i Müslim. thk. Muhammed Fuad Abdulbâkî. 4 Cilt. Beyrut: Dâru İhyâi't-Turâsi'l-Arabî, trs.

Nesefî, Ömer. Metn-i Akâid. çev. H. Tahsin Feyizli. İstanbul, 1988.

Pinker, Steven. Boş Sayfa. çev. Mehmet Doğan. 3. Basım. İstanbul: Boğaziçi Üniversitesi Yayınevi, 2016.

Platon. Devlet. çev. Sabahattin Eyüboğlu-M. Ali Cimgöz. İstanbul: İş Bankası Yayınları, 2010.

Rağıb el-İsfehânî, Ebu'l-Kasım Huseyn. Tefsiru'r-Rağıb el-İsfefehanî. thk. Hind binti Muhammed. 5 Cilt. Câmiatu Ümmi'l-Kurâ, 2001.

Ranisch, Robert- Sorgner, Stefan Lorenz (ed.). Post-and Transhumanism. Frankfurt: Peter Lang, 2014.

Râzî, Ebu Abdillah Muhammed b. Ömer. Mefâtihu'l-ğayb. 32 Cilt. Beyrut: Dâru İhyâi'tMarife 21/1 (2021): 11-36 
Turâsi'l-Arabî, 1420.

Reşid Rıza. Tefsiru'l-menâr. 12 Cilt. b.y.: el-Hey'etu'l-Mısriyye, 1990.

Sem'anî, Ebu'l-Muzaffer Mansûr. Tefsiru'l-Kur'an. thk. Yasir b. İbrahim. 6 Cilt. Riyad: Dâru'lVatan, 1997.

Sevrî, Ebu Abdillah Süfyan b. Said. Tefsiru's-Sevrî. Beyrut: Dâru'l-Kütübi'l-İlmiyye, 1983.

Şirbînî, Şemsuddin Muhammed Hatib. es-Sirâcu'l-münîr. 4 Cilt. Kahire: Matbaatu Bûlak, 1285.

Taberî, Ebu Cafer Muhammed b. Cerir. Câmiu'l-beyân an te'vil-i âyi'l-Kur'an. 24 Cilt. Mekke: Dâru't-Terbiye ve't-Turâs, trs.

Taftezânî, Mes'ud b. Ömer b. Sadeddin. Şerhu'l-makâsıd. thk. Dr. Abdurrahman Umeyra. 5 Cilt. Beyrut: Âlemu'l-Kütüb, 1998.

Tayalisî, Ebu Davud Süleyman b. Davud. el-Müsned. thk. Dr. Muhammed b. Abdilmuhsin. 4 Cilt. Mısır: Dâru Hecer, 1999.

Tirmizî, Muhammed b. İsa. Sünenu't-Tirmizî. thk. Beşşar Avvâd. 6 Cilt. Beyrut: Dâru'l-Ğarbi'lİslamî, 1998.

Vahidî, Ebu'l-Hasen Ali b. Ahmed. el-Vasît fî tefsiri'l-Kur'ani'l-mecîd. thk. Âdil Ahmed vd. 4 Cilt. Beyrut: Dâru'l-Kütübi'l-İlmiyye, 1994.

Yıldırım, Abdurrahman Ali. Tıp Hukuku Bağlamında İnsanı Geliştiren Biyoteknoloji Uygulamaları. İstanbul: Medeniyet Üniversitesi, Sosyal Bilimler Enstitüsü, Yüksek Lisans Tezi, 2019.

Zeccâc, Ebu İshak İbrahim b. es-Serî. Meâni'l-Kur'an ve i'rabuh. thk. Abdulcelil Abde. 5 Cilt. Beyrut: Âlemu'l-Kütüb, 1988.

Zizek, Slavoj. Cinsel Olan Politik Midir?. çev. Bahadır Turan. İstanbul: Encore Yayınları, 2018. 